\title{
Impact of metal oxide nanoparticles on cotton (Gossypium hirsutum L.): a physiological perspective
}

\author{
SINGH BRAR Ravinderdeep', KUMAR Avneesh², KAUR Simranjeet ${ }^{2}$, SAHA Sandip ${ }^{1}$, KUMAR Anuj $^{3}$ and \\ KUMAR Sandeep ${ }^{1 *}$ (D)
}

\begin{abstract}
Cotton production substantiated a crucial part in the escalating economic development of many countries. To realize the increasing global demand for cotton, the emphasis should be laid on to improve cotton fiber growth and production. The bioengineered transgenic cotton proved expedient in resolving inadequacies of conventional cotton, but still required improvements to encounter heightened demand of textile industries. One possible solution pertaining to this has been provided by nanoscience in the form of metal or metal oxide nanoparticles. These metal oxide nanoparticles have easy access to the various parts of cotton plants through its transportation system, and thus significantly influence several parameters relative to the growth and production of cotton fiber. This review summarizes the distribution and accumulation of metal oxide nanoparticles in cotton plant and its impact on different plant growth-promoting factors, which resulted in the improved cotton yields.
\end{abstract}

Keywords: Cotton, Bt-transgenic, Nanoparticles, Metal oxide nanoparticles, Phytohormones, Superoxide dismutase, Nutrient element

\section{Background}

Cotton, Gossypium hirsutum L. (Malvaceae), is a natural plant fiber of great economic significance, grown worldwide and now dominates the natural textile industry (Wegier et al. 2016). Additionally, cottonseed is a well-known livestock and poultry feed rich in fiber (24\%), fat (20\%) and protein (23\%). Refined and deodorized cottonseed oil is one of the nutritious edible oils due to the presence of high levels of antioxidants such as tocopherol (Nix et al. 2017; Yang et al. 2019; Yang et al. 2017). The supply, however, has not grown proportionately to its diverse uses. Further, the gap between demand and supply has widened with the exponential growth of the population. To fill this gap, a genetically-modified Btcotton comprising the parasporal crystal protein genes of bacteria Bacillus thuringiensis (Bt) with insecticidal proteins

\footnotetext{
* Correspondence: sandeepchem83@gmail.com

'Department of Chemistry, Akal University, Talwandi Sabo, Bathinda, Punjab 151302, India

Full list of author information is available at the end of the article
}

( $\delta$-endotoxin) was developed with many advantages over conventional cotton to improve yield, quality, and pest resistance, etc., which has encouraged the commercialization of the transgenic cotton in recent years (Abdelmoteleb et al. 2018; Roh et al. 2007). The high yield Bt-cotton resulted in a $30 \%$ reduction of the land area used for cotton cultivation globally over the last 30 years, as well as the global cotton production has increased around 400\% (Mehboob-ur-Rahman et al. 2012; Witjaksono et al. 2014). Many factors such as climate (temperature, light, rainfall, dew, wind, etc.), duration of growing season, availability of nutrients, relative humidity, soil moisture, pests, heavy metal contamination and cultivation practices may have unexpected responses to the growth of cotton plants (Sawan 2017; Mei et al. 2018; Xu et al. 2019). The target for the improved cotton yield can be realized by using advanced agricultural technologies and genetically-improved cotton breeds, understanding of climatic conditions, and soil fertilizer management, etc. (Thorp et al. 2014). Other than these technological developments for

(c) The Author(s). 2021 Open Access This article is licensed under a Creative Commons Attribution 4.0 International License, which permits use, sharing, adaptation, distribution and reproduction in any medium or format, as long as you give appropriate credit to the original author(s) and the source, provide a link to the Creative Commons licence, and indicate if changes were made. The images or other third party material in this article are included in the article's Creative Commons licence, unless indicated otherwise in a credit line to the material. If material is not included in the article's Creative Commons licence and your intended use is not permitted by statutory regulation or exceeds the permitted use, you will need to obtain permission directly from the copyright holder. To view a copy of this licence, visit http://creativecommons.org/licenses/by/4.0/ 
improving crop production, the utilization of metal or metal oxide based nanoparticles is a relatively new topic of study.

Nanoparticles (NPs) have been widely utilized for the different applications like biosensing (Salata 2004; Nehra et al. 2019), biofuel production (Sekoai et al. 2019), and organic and photochemical reactions (Song 2015), etc. The major advantage of nanofertilizer is that these are not only the best micro-nutrients but also aids in reclamation of soil. There are several reports where the presence of a certain amount of various nanoparticles has shown substantial beneficial effects on different plant species. (Nair 2016; Zhu et al. 2019; Kumar et al. 2019; Rastogi et al. 2017). However, the influence of a particular nanoparticle is dependent upon the dose, type, shape, structure, solubility and duration of the treatment (Aslani et al. 2014). NPs are prepared either with organic polymers (organic NPs) and/or inorganic elements (inorganic NPs). Inorganic NPs includes metals like Aluminium (Al), Cobalt (Co), Bismuth (Bi), Iron (Fe), Copper $(\mathrm{Cu})$, Gold $(\mathrm{Au})$, Molybdenum (Mo), Nickel (Ni), Tin $(\mathrm{Sn})$, Silver (Ag), Titanium (Ti), Tungsten (W), Zinc $(\mathrm{Zn})$, metal oxides $\left(\mathrm{SnO}_{2}, \mathrm{Al}_{2} \mathrm{O}_{3}, \mathrm{In}_{2} \mathrm{O}_{3}, \mathrm{CuO}, \mathrm{ZrO}_{2}\right.$, $\mathrm{Cu}_{2} \mathrm{O}, \mathrm{MgO}, \mathrm{La}_{2} \mathrm{O}_{3}, \mathrm{NiO}, \mathrm{ZnO}, \mathrm{TiO}_{2}, \mathrm{CeO}_{2}$ ) and quantum dots, while liposomes, dendrimers, carbon nanomaterials, and polymeric micelles are examples of bio-organic NPs (Rajput et al. 2017; Nie et al. 2010; Kango et al. 2013). NPs get absorbed 15-20 times more by the plants than the bulk nutrients (Lv et al. 2019; Srivastav et al. 2016). NPs have been deployed in agriculture to escalate the rate of seed germination and plant growth (Vera-Reyes et al. 2018) and also to protect plants from various abiotic stresses such as high and/or low temperature, salinity, drought, and flooding, and biotic stress such as fungi, bacteria, and insects (Jalil and Ansari, 2019, Elhawat et al. 2018; Hao et al. 2018; Hao et al. 2017).

\section{Recent beneficial applications of nanoparticles in plants}

Silicon is found beneficial for plants under stress and help to rescue from drought stress as well as from micronutrient and other metal toxicities, i.e., copper, aluminum, iron, zinc, etc. (Siddiqui et al. 2015; Emamverdian et al. 2018). $\mathrm{Nano}^{-\mathrm{SiO}_{2}}$ also affects maize seed germination positively by making available nutrients in better amounts, adjusting the $\mathrm{pH}$ and conductivity to the growing medium (Suriyaprabha et al. 2012). Quantum dot (QD) and silica-coated quantum dot have also been used for the study of root growth in rice plants (Wang et al. 2014). ZnONPs has been used to investigate the seed germination process in soybean, wheat, and onion and exhibits a beneficial effect under the lower concentration (Ali et al. 2021; Boonyanitipong et al. 2011; Sedghi et al. 2013; Raskar and Laware 2014). Additionally, some experiments on in vitro cultures and organogenic renaissance of bananas supplemented with $\mathrm{ZnONPs}$ and found promoting effect on somatic embryogenesis and reconstruction of plantlets. A noticeable elevated level of antioxidant enzymes (SOD, POD, and CAT) and biochemicals (such as proline) were found responsible for the observed tolerance to various biotic stresses (Helaly et al. 2014). A study to assess the effect of ZnONPs in tomato plants showed significant improvement in growth, photosynthetic efficacy, carbonic anhydrase, and free radical scavenging activity (Faizan et al. 2018). Carbon based nanoparticles in the form of carbon nanotubes (CNTs) have been widely employed for the promotion of plant growth. The CNTs delivered into chloroplast, worked as artificial antennae, were capable of capturing light of different wavelengths (ultraviolet, green, and near-infrared), and hence, enhanced the seed germination, growth, and overall development in plants (Patel et al. 2017; Mukesh and Jha 2017; Siddiqui et al. 2015; Lahiani et al. 2013). The ability of the single and multiwalled CNTs to penetrate the plant cell has also been explored to develop the delivery system for DNA and other biochemicals (Lara-Romero et al. 2017; Oloumi et al. 2018; Srinivasan and Saraswathi 2010). Multi-walled CNTs were found a possible influencing factor for improved seed germination and plant growth in important crop plants (barley, corn, soybean) by inducing water and essential nutrients ( $\mathrm{Fe}$ and $\mathrm{Ca}$ ) uptake efficacy. Multi-walled CNTs also have a generegulating effect on various kinds of water channel proteins in soybean, barley, and corn (Lahiani et al. 2013). Noble metal nanoparticles such as $\mathrm{Au}$ and $\mathrm{Ag}$ have also been used for several crops and non-crop plants (Dykman and Shchyogolev 2018). Improved seed germination has been observed in lettuce (Lactuca sativa) (Barrena et al. 2009), mustard (Brassica juncea) (Arora et al. 2012; Sharma et al. 2012), common bean (Phaseolus vulgaris), and corn (Zea mays) (Salama 2012). Further, the improvement in the number of leaves, leaf area, plant height, chlorophyll content, and sugar content has also been reported, which resulted in better crop yield (Arora et al. 2012; Gopinath et al. 2014). In a study, Arabidopsis thaliana was treated with AuNPs and its remarkable effects on seed germination and free radical scavenging activity were noticed (Kumar et al. 2013). In this study, the expression levels of various miRNAs was also found correlated with seed germination, growth, and antioxidant potential. Interestingly, in a study where the NPs morphology-based effects were analyzed, the decahedral shaped AgNPs were found to have maximum root growth promoting effect; while, the sphericalshaped showed the maximum anthocyanin accumulation in Arabidopsis seedlings, but had no effect on root growth (Syu et al. 2014). The effects of conventionally synthesized and plant extract-based green AgNPs were compared in terms of their effects on Phaseolus vulgaris growth, as well as soil physicochemical properties. Under the low dose treatment of green AgNPs, the leaf number, leaf area index, pod yield, and nitrate reductase activity, etc., were found remarkably improved in comparison with conventional AgNPs. These 
nanoparticles had also successfully modified the soil $\mathrm{pH}$ from originally acidic to neutral range, and thus, remarkably improved the cation exchange capacity, water holding capacity, and N/P content (Das et al. 2018).

Similar to these above discussed NPs, some other NPs such as Manganese (Mn), Titanium (Ti), etc., were also analyzed for their impacts on different plants (Pradhan et al. 2013; Jacob et al. 2013; Jaberzadeh et al. 2013). $\mathrm{TiO}_{2} \mathrm{NPs}$ elevated the growth of Brassica napus and Triticum aestivum (Mahmoodzadeh et al. 2013; Jaberzadeh et al. 2013). A study on Triticum aestivum to analyze the effect of nano $\mathrm{Mn}_{2} \mathrm{O}_{3}$ (spherical-shaped, $30 \mathrm{~nm}$ size) along with bulk $\mathrm{Mn}_{2} \mathrm{O}_{3}$, and manganese chloride $\left(\mathrm{MnCl}_{2} \cdot 4 \mathrm{H}_{2} \mathrm{O}\right)$ resulted in declined nitrogen content in the plant shoot by $9-18 \%$. However, MnNPs in soil reduced the $\mathrm{Mn}, \mathrm{P}$, and $\mathrm{K}$ contents in the shoot by 25,33 and $7 \%$, respectively, while soil residual nitrate- $\mathrm{N}$ content were increased by $30 \%$. The translocation efficiency of $\mathrm{Mn}$ was increased in the grain by nano $\mathrm{Mn}_{2} \mathrm{O}_{3}$, in comparison to other forms, i.e., salt and bulk-Mn. However, foliar exposure of MnNPs showed improved Mn contents in shoot and grain, $\mathrm{P}$ content in shoot, along with lesser soil nitrate (Dimkpa et al. 2018). $\mathrm{TiO}_{2}$ nanoparticle induced elevated growth of Brassica napus was observed via concentration dependent improved radicle and plumule growth resulting in enhanced seed germination and seedling vigor (Mahmoodzadeh et al. 2013). The effect of foliar application of nano and bulk $\mathrm{TiO}_{2}$ was studied to evaluate the agronomic traits such as height, ear weight and number, seed number and weight, seed gluten and starch contents under water deficit stress conditions in Triticum aestivum. The nano $\mathrm{TiO}_{2}$ foliar treatment resulted in increased agronomic traits in comparison to bulk $\mathrm{TiO}_{2}$ NPs (Jaberzadeh et al. 2013).

\section{Disadvantages of nanoparticles on plants or ecological environments}

In recent years, various metal NPs have been used as nanopesticides to restrict the attack of different pests and microbes (Worrall et al. 2018; Deshpande 2019), nanoherbicides to reduce the negative effects of herbicides (Abigail and Chidambaram 2017) and nanofertilizers to improve productivity and natural fertility in plants by conquering the deficiencies of micronutrients (Bala et al. 2019). Along with their beneficial impacts, metal-based NPs are also applied and monitored for their harmful effects on flora and fauna (Jeevanandam et al. 2018; Ebrahimi et al. 2016; McGee et al. 2017; Priester et al. 2017; Rajput et al. 2018; Singh and Kumar 2016). Nanotoxicology helps to recognize the interaction mechanisms of a nanomaterial with plants or animals (Hobson 2016). The toxicity or poisonous level of NPs is not directly related to its dose or exposure concentration, but to the parameters like size, surface activity, number, aggregate formation etc. (Singh 2016). The concentration dependent toxicity effect of rare earth metal oxides and their respective metals were observed on the aquatic microorganisms Vibrio fischeri and Tetrahymena thermophila (Kurvet et al. 2017).

These days, various reports show that NPs could be a health hazard and toxicity at primary level or secondary level as they could get entered in the food chain through plants. Presence of various nanoparticles $\left(\mathrm{TiO}_{2}, \mathrm{ZnO}, \mathrm{Ag}\right.$ NPs, etc.) in cosmetics are also very common and could penetrate the human skin (Fytianos et al. 2020). The NPs damage mitochondria (Meyer et al. 2011; Assadian et al. 2018), leakage in lysosomal membrane of blood lymphocytes (Assadian et al. 2018), reduce cell viability etc. (Umar et al. 2019) which ultimately harms the cells. NPs can also show toxicity by inducing oxidative stress that causes cell damage, increased inflammation, and altered immune responses (Shabbir et al. 2021).

NPs that are being used in agriculture are also found toxic for crops too. NPs were found toxic for the crop plants like to Triticum aestivum (Gorczyca et al. 2021), Tobacco (Peharec et al. 2021; Biba et al. 2021), Oryza sativa (Thuesombat et al. 2014), Arabidopsis thaliana (Sosan et al. 2016), Hordeum vulgare (El-Temsah and Joner 2012), Lettuce sativa (Ruttkay-Nedecky et al. 2017), Vicia faba (Falco et al. 2020) Pisum sativum (Mukherjee et al. 2016), etc.

The impact of various metal/metal oxide nanoparticles on the growth and production of major cultivation crops have always remained a topic of great interest (Table 1). Therefore, in this comprehensive review, we are going to represent those literature reports, where the impacts of various metal or metal oxide-based nanoparticles have been explored on the physiological parameters of cotton plants (Fig. 1).

\section{Distribution/accumulation of nanoparticles in cotton plant}

Before going into the detail of various aspects of NPs impact on the transgenic or non-transgenic cotton plant, it is necessary to have insight into the distribution of nanomaterials in various parts of the cotton plant upon treatment with different concentrations of nanomaterials. In this section, the uptake, distribution, and the accumulation of various nanomaterials (viz. $\mathrm{CeO}_{2}, \mathrm{CuO}$, $\mathrm{Fe}_{2} \mathrm{O}_{3}$, and $\mathrm{SiO}_{2}$ ) in cotton plants will be discussed.

In both transgenic (Bt 29317) and non-transgenic (Jihe 321) cotton, most of the $\mathrm{CeO}_{2}$ NPs aggregates were found to accumulate in the outer epidermis of the root, with fewer in the intercellular spaces as confirmed by ICP-MS analysis, which reflects the poor penetration tendencies of $\mathrm{CeO}_{2} \mathrm{NPs}$ into roots of plants ( $\mathrm{Li}$ et al. 2014). The transgenic cotton exhibits greater accumulation of $\mathrm{CeO}_{2} \mathrm{NPs}$ in the intercellular spaces than 
Table 1 Impact of various metal/metal oxide nanoparticles on major cultivation crops

\begin{tabular}{|c|c|c|c|c|c|}
\hline $\begin{array}{l}\text { Metal/Metal } \\
\text { oxide } \\
\text { nanoparticles } \\
\end{array}$ & Concentrations & Plant/Crops & $\begin{array}{l}\text { Exposure } \\
\text { Methodology }\end{array}$ & Physiological Impacts on plants & Reference \\
\hline \multirow[t]{2}{*}{ Au NPs } & $0-10 \mathrm{mg} \mathrm{L}^{-1}$ & $\begin{array}{l}\text { Mustard greens } \\
\text { (Brassica juncea) }\end{array}$ & Field & $\begin{array}{l}\text { Improved seedling growth with increased productivity in } \\
\text { terms of seed yield }\end{array}$ & Arora et al. 2012 \\
\hline & $0-100 \mathrm{mg} \mathrm{L}^{-1}$ & $\begin{array}{l}\text { Arabidopsis } \\
\text { (Arabidopsis } \\
\text { thaliana L.) }\end{array}$ & $\begin{array}{l}\text { Growth } \\
\text { chamber }\end{array}$ & Decrease in root length with increased dose of NPs & $\begin{array}{l}\text { Taylor et al. } \\
2014\end{array}$ \\
\hline \multirow[t]{7}{*}{ Ag NPs } & $\begin{array}{l}0-5000 \mathrm{mg} \\
\mathrm{L}^{-1}\end{array}$ & $\begin{array}{l}\text { Barley (Hordeum } \\
\text { vulgare L.), } \\
\text { Ryegrass } \\
\text { (Lolium perenne } \\
\text { L.) }\end{array}$ & $\begin{array}{l}\text { Growth } \\
\text { chamber }\end{array}$ & Decrease in seed germination and shoot length & $\begin{array}{l}\text { El-Temsah and } \\
\text { Joner } 2012\end{array}$ \\
\hline & $1-10 \mathrm{mg} \mathrm{L}^{-1}$ & $\begin{array}{l}\text { Lettuce } \\
\text { (Lactuca sativa), } \\
\text { Barley (Hordeum } \\
\text { vulgare L.) }\end{array}$ & $\begin{array}{l}\text { Growth } \\
\text { chamber }\end{array}$ & $\begin{array}{l}\text { Significant increase in root length for barely and reduction in } \\
\text { case of lettuce, }\end{array}$ & $\begin{array}{l}\text { Gruyer et al. } \\
2013\end{array}$ \\
\hline & $20-100 \mathrm{mg} \mathrm{L}^{-1}$ & $\begin{array}{l}\text { Common bean } \\
\text { (Phaseolus } \\
\text { vulgaris L.) }\end{array}$ & Field & $\begin{array}{l}\text { Protein content increased up to } 60 \mathrm{~g} \cdot \mathrm{kg}^{-1} \text { concentration of } \\
\text { Ag NPs. Further increase show toxic effects }\end{array}$ & Salama 2012 \\
\hline & & $\begin{array}{l}\text { Corn (Zea mays } \\
\text { L.) }\end{array}$ & & & \\
\hline & $0-100 \mathrm{mg} \mathrm{L}^{-1}$ & $\begin{array}{l}\text { Mungbean } \\
\text { (Phaseolus } \\
\text { radiatus) }\end{array}$ & $\begin{array}{l}\text { Growth } \\
\text { chamber }\end{array}$ & Reduction in seedling growth, less toxicity in soil medium & Lee et al. 2012 \\
\hline & $0-40 \mathrm{mg} \mathrm{L}^{-1}$ & $\begin{array}{l}\text { Sorghum } \\
\text { (Sorghum } \\
\text { bicolor) }\end{array}$ & & & \\
\hline & $0-1 \mathrm{mg} \mathrm{L}^{-1}$ & $\begin{array}{l}\text { Rice (Oryza } \\
\text { sativa L.) }\end{array}$ & $\begin{array}{l}\text { Growth } \\
\text { chamber }\end{array}$ & $\begin{array}{l}\text { Significant decrease in root growth, plant biomass, total } \\
\text { chlorophyll and carotenoids content and photosynthetic } \\
\text { pigments in rice seedlings }\end{array}$ & $\begin{array}{l}\text { Nair and Chung } \\
2014\end{array}$ \\
\hline \multirow[t]{7}{*}{$\mathrm{Al}_{2} \mathrm{O}_{3}$} & $2000 \mathrm{mg} \mathrm{L}^{-1}$ & Corn (Zea mays) & $\begin{array}{l}\text { Growth } \\
\text { chamber }\end{array}$ & Inhibition in root elongation & $\begin{array}{l}\text { Lin and Xing } \\
2007\end{array}$ \\
\hline & $0.02-20 \mathrm{~g} \cdot \mathrm{L}^{-1}$ & $\begin{array}{l}\text { Cucumber } \\
\text { (Cucumis } \\
\text { sativus) }\end{array}$ & $\begin{array}{l}\text { Growth } \\
\text { chamber }\end{array}$ & Inhibition in root elongation & $\begin{array}{l}\text { Yang and Watts } \\
2005\end{array}$ \\
\hline & & $\begin{array}{l}\text { Soybean } \\
\text { (Glycine max) }\end{array}$ & & & \\
\hline & & $\begin{array}{l}\text { Cabbage } \\
\text { (Brassica } \\
\text { oleracea) }\end{array}$ & & & \\
\hline & & $\begin{array}{l}\text { Carrot (Daucus } \\
\text { carota) }\end{array}$ & & & \\
\hline & $400-4000 \mathrm{~g} \cdot \mathrm{L}^{-1}$ & $\begin{array}{l}\text { Arabidopsis } \\
\text { (Arabidopsis } \\
\text { thaliana L.) }\end{array}$ & $\begin{array}{l}\text { Growth } \\
\text { chamber }\end{array}$ & Significant Increase in root elongation & Lee et al. 2010 \\
\hline & $50 \mathrm{mg} / \mathrm{ml}$ & $\begin{array}{l}\text { Wheat (Triticum } \\
\text { aestivum) }\end{array}$ & $\begin{array}{l}\text { Growth } \\
\text { chamber }\end{array}$ & $\begin{array}{l}\text { Reduction in root elongation, lignin deposition, cellular } \\
\text { deformation, increase in peroxidase activity and decrease in } \\
\text { total protein content }\end{array}$ & $\begin{array}{l}\text { Yanık and } \\
\text { Vardar } 2015\end{array}$ \\
\hline \multirow[t]{4}{*}{$\mathrm{CeO}_{2}$} & $0.1-10 \mathrm{mg} \mathrm{L}^{-1}$ & $\begin{array}{l}\text { Tomato } \\
\text { (Solanum } \\
\text { lycopersicum L.) }\end{array}$ & Green house & $\begin{array}{l}\text { Increased plant growth and production with accumulation of } \\
\text { Ce in tomato fruit }\end{array}$ & $\begin{array}{l}\text { Wang et al. } \\
2012 a\end{array}$ \\
\hline & $\begin{array}{l}500-2000 \mathrm{mg} \\
\mathrm{L}^{-1}\end{array}$ & $\begin{array}{l}\text { Arabidopsis } \\
\text { (Arabidopsis } \\
\text { thaliana L.) }\end{array}$ & Glasshouse & $\begin{array}{l}\text { Reduction in plant growth and chlorophyll content at higher } \\
\text { concentration }\end{array}$ & Ma et al. 2013 \\
\hline & $0-500 \mathrm{mg} \cdot \mathrm{kg}^{-1}$ & \multirow{2}{*}{$\begin{array}{l}\text { Wheat (Triticum } \\
\text { aestivum) }\end{array}$} & Field & Significant increase plant height, biomass, and grain yield & Du et al. 2015 \\
\hline & $0-400 \mathrm{mg} \cdot \mathrm{kg}^{-1}$ & & Greenhouse & $\begin{array}{l}\text { Toxic to wheat seedlings and increase in grain protein } \\
\text { content }\end{array}$ & Rico et al. 2014 \\
\hline
\end{tabular}


Table 1 Impact of various metal/metal oxide nanoparticles on major cultivation crops (Continued)

\begin{tabular}{|c|c|c|c|c|c|}
\hline $\begin{array}{l}\text { Metal/Metal } \\
\text { oxide } \\
\text { nanoparticles }\end{array}$ & Concentrations & Plant/Crops & $\begin{array}{l}\text { Exposure } \\
\text { Methodology }\end{array}$ & Physiological Impacts on plants & Reference \\
\hline $\mathrm{CeO}_{2} \& \mathrm{ZnO}$ & $0-800 \mathrm{mg} \cdot \mathrm{kg}^{-1}$ & $\begin{array}{l}\text { Cucumber } \\
\text { (Cucumis } \\
\text { sativus) }\end{array}$ & Greenhouse & Bioaccumulation of $\mathrm{Ce}$ and $\mathrm{Zn}$ & Zhao et al. 2013 \\
\hline $\mathrm{Cr}_{2} \mathrm{O}_{3}$ & $0-100 \mathrm{mg} \cdot \mathrm{L}^{-1}$ & $\begin{array}{l}\text { Wheat (Triticum } \\
\text { aestivum) }\end{array}$ & $\begin{array}{l}\text { Growth } \\
\text { chamber }\end{array}$ & $\begin{array}{l}\text { Inhibition of seed germination, biomass, shoot and root } \\
\text { length }\end{array}$ & $\begin{array}{l}\text { Vajpayee et al. } \\
2011\end{array}$ \\
\hline \multirow[t]{2}{*}{$\mathrm{CuO}$} & $10-100 \mathrm{mg}^{-1}$ & $\begin{array}{l}\text { Maize (Zea } \\
\text { mays L.) }\end{array}$ & $\begin{array}{l}\text { Growth } \\
\text { chamber }\end{array}$ & No effect on seed germination & $\begin{array}{l}\text { Wang et al. } \\
2012 b\end{array}$ \\
\hline & $0-1000 \mathrm{mg} \cdot \mathrm{L}^{-1}$ & $\begin{array}{l}\text { Rice (Oriza } \\
\text { sativa var. Jyoti) }\end{array}$ & $\begin{array}{l}\text { Growth } \\
\text { chamber }\end{array}$ & $\begin{array}{l}\text { Increased level of oxidative and osmotic stress, decrease in } \\
\text { germination rate, root and shoot length, and biomass }\end{array}$ & $\begin{array}{l}\text { Da Costa and } \\
\text { Sharma } 2016\end{array}$ \\
\hline $\mathrm{Fe}_{3} \mathrm{O}_{4} \& \mathrm{ZnO}$ & $0-20 m g \mathrm{~L}^{-1}$ & $\begin{array}{l}\text { Wheat (Triticum } \\
\text { aestivum) }\end{array}$ & Field & Increase in nutrients, biomass and decreased $\mathrm{Cd}$ toxicity & $\begin{array}{l}\text { Rizwan et al. } \\
2019\end{array}$ \\
\hline \multirow[t]{2}{*}{$\mathrm{Fe}_{3} \mathrm{O}_{4}$} & $0-100 \mu L \cdot L^{-1}$ & $\begin{array}{l}\text { Sunflower } \\
\text { (Helianthus } \\
\text { annuus L.) }\end{array}$ & $\begin{array}{l}\text { Growth } \\
\text { chamber }\end{array}$ & Reduction in chlorophyll content & $\begin{array}{l}\text { Ursache-Oprisan } \\
\text { et al. } 2011\end{array}$ \\
\hline & $2000 \mathrm{mg} \cdot \mathrm{L}^{-1}$ & $\begin{array}{l}\text { Wheat (Triticum } \\
\text { aestivum) }\end{array}$ & $\begin{array}{l}\text { Growth } \\
\text { chamber }\end{array}$ & $\begin{array}{l}\text { Growth inhibition \& reduce oxidative stress induced by heavy } \\
\text { metals ( } \mathrm{Zn}, \mathrm{Pb}, \mathrm{Cu} \text { and } \mathrm{Cd})\end{array}$ & $\begin{array}{l}\text { Konate et al. } \\
2017\end{array}$ \\
\hline $\mathrm{SiO}_{2}$ & $0-100 \mathrm{mg} \cdot \mathrm{L}^{-1}$ & $\begin{array}{l}\text { Rice (Oriza } \\
\text { sativa L.) }\end{array}$ & $\begin{array}{l}\text { Growth } \\
\text { chamber }\end{array}$ & Positive effect on seed germination and seedlings growth & $\begin{array}{l}\text { Adhikari et al. } \\
2013\end{array}$ \\
\hline \multirow[t]{2}{*}{$\mathrm{TiO}_{2}$} & $0-400 \mathrm{mg} \cdot \mathrm{L}^{-1}$ & $\begin{array}{l}\text { Tomato } \\
\text { (Lycopersicum } \\
\text { esculentum L.) } \\
\text { Onion (Allium } \\
\text { cepa L.) } \\
\text { Radish } \\
\text { (Raphanus } \\
\text { sativus L.) }\end{array}$ & Green House & $\begin{array}{l}\text { Improved seed germination at } 100 \text { and } 200 \mathrm{mg}^{-1} \mathrm{~L}^{-1} \\
\text { concentration }\end{array}$ & $\begin{array}{l}\text { Haghighi and } \\
\text { da Silva, } 2014\end{array}$ \\
\hline & $100 \mathrm{mg} \mathrm{L}^{-1}$ & $\begin{array}{l}\text { Wheat (Triticum } \\
\text { aestivum) }\end{array}$ & $\begin{array}{l}\text { Growth } \\
\text { chamber }\end{array}$ & No effect on seed germination and total biomass & Larue et al. 2012 \\
\hline \multirow[t]{2}{*}{$\mathrm{TiO}_{2} \& \mathrm{ZnO}$} & $\begin{array}{l}100-500 \\
\mathrm{mg} \cdot \mathrm{kg}^{-1}\end{array}$ & $\begin{array}{l}\text { Wheat (Triticum } \\
\text { aestivum) }\end{array}$ & Field & Reduced plant Growth & Du et al. 2011 \\
\hline & $0-1000 \mathrm{mg} \cdot \mathrm{L}^{-1}$ & $\begin{array}{l}\text { Rice (Oriza } \\
\text { sativa L.) }\end{array}$ & $\begin{array}{l}\text { Growth } \\
\text { chamber }\end{array}$ & Root elongation inhibition with decreased number of roots & $\begin{array}{l}\text { Boonyanitipong } \\
\text { et al. } 2011\end{array}$ \\
\hline \multirow[t]{5}{*}{$\mathrm{ZnO}$} & $0-500 \mathrm{mg} \cdot \mathrm{kg}^{-1}$ & $\begin{array}{l}\text { Soybean } \\
\text { (Glycine max L.) }\end{array}$ & Green House & Reduced growth of plant & Yoon et al. 2014 \\
\hline & $\begin{array}{l}400-2000 m g \\
L^{-1}\end{array}$ & $\begin{array}{l}\text { Peanut (Arachis } \\
\text { hypogaea) }\end{array}$ & $\begin{array}{l}\text { Growth } \\
\text { chamber }\end{array}$ & $\begin{array}{l}1 \mathrm{~g}^{-1} \mathrm{~L}^{-1} \mathrm{NPs} \text { concentration improved seedling germination } \\
\text { but showed negative effect at } 2 \mathrm{~g} \mathrm{~L}^{-1}\end{array}$ & $\begin{array}{l}\text { Prasad et al. } \\
2012\end{array}$ \\
\hline & $\begin{array}{l}0-1600 \mathrm{mg} \\
\mathrm{L}^{-1}\end{array}$ & $\begin{array}{l}\text { Tomato } \\
\text { (Solanum } \\
\text { lycopersicum L.) } \\
\text { Alfalfa } \\
\text { (Medicago } \\
\text { sativa) } \\
\text { Cucumber } \\
\text { (Cucumis } \\
\text { sativus) }\end{array}$ & $\begin{array}{l}\text { Growth } \\
\text { chamber }\end{array}$ & $\begin{array}{l}\text { Germination rate reduced in Tomato and Alfalfa but } \\
\text { increased in Cucumber }\end{array}$ & $\begin{array}{l}\text { de la Rosa et al. } \\
2013\end{array}$ \\
\hline & $0-500 \mathrm{mg} \cdot \mathrm{kg}^{-1}$ & $\begin{array}{l}\text { Green peas } \\
\text { (Pisum sativum } \\
\text { L.) }\end{array}$ & Field & Increased root elongation & $\begin{array}{l}\text { Mukherjee et al. } \\
2014\end{array}$ \\
\hline & $0-16 \mathrm{mg} \cdot \mathrm{L}^{-1}$ & $\begin{array}{l}\text { Tomato } \\
\text { (Lycopersicum } \\
\text { esculentum L.) }\end{array}$ & Net house & $\begin{array}{l}\text { Increased growth, enhanced photosynthetic efficiency at } 8 \\
m g L^{-1} \text { treatment }\end{array}$ & $\begin{array}{l}\text { Faizan et al. } \\
2018\end{array}$ \\
\hline
\end{tabular}




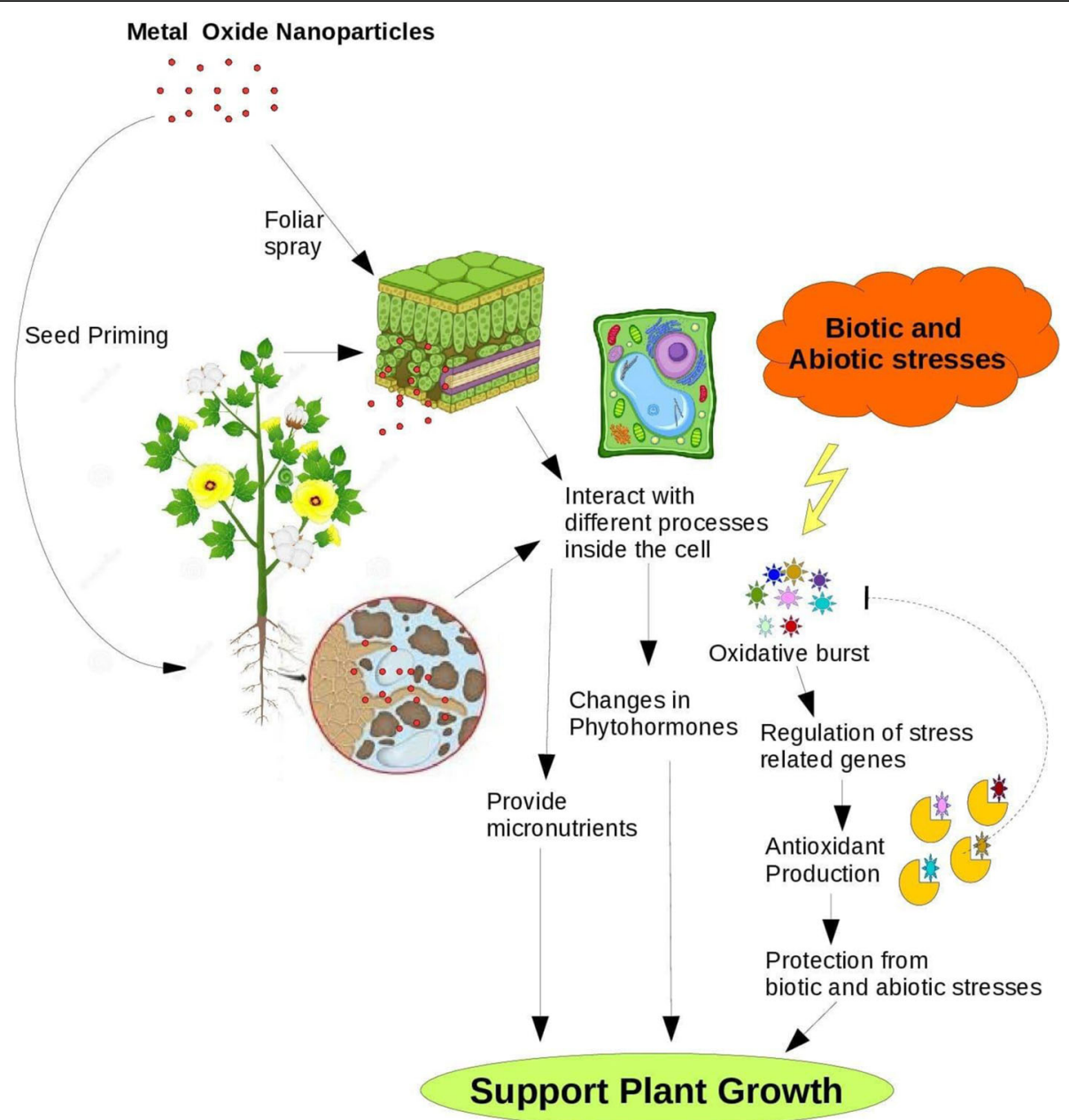

Fig. 1 Schematic representation of impact of nanoparticles on the physiological parameters of cotton plant

the conventional cotton as observed in transmission electron microscope (TEM) images of roots of conventional (A) and Bt-transgenic cotton (B) under 500 mg.L ${ }^{-1} \mathrm{CeO}_{2}$ NPs treatments (Fig. 2). The enhanced accumulation of $\mathrm{CeO}_{2}$ NPs aggregates was observed in the leaves and stems of both Bt-transgenic cotton and conventional cotton, but to different extents, when these cotton plants were treated with increased concentrations of $\mathrm{CeO}_{2}$ NPs. The Ce content was nearly 1.8 times higher in leaves and stem of Bt-cotton compared with the conventional cotton, when treated with lower concentrations $\left(100 \mathrm{mg} \cdot \mathrm{L}^{-1}\right.$ ) of $\mathrm{CeO}_{2} \mathrm{NPs}$ solutions. But the Ce content was significantly increased in the leaves and stems of Bt-transgenic cotton, when the dose of $\mathrm{CeO}_{2}$ NPs solution was increased to $500 \mathrm{mg} \cdot \mathrm{L}^{-1}$ and was approximately three-fold as compared with that observed in the conventional cotton ( $\mathrm{Li}$ et al. 2014; Nhan et al. 2015).

These results revealed that after uptake by the root system, the $\mathrm{CeO}_{2} \mathrm{NPs}$ were transported to the leaves and stem in both transgenic and nontransgenic cotton. The greater accumulation of $\mathrm{CeO}_{2} \mathrm{NPs}$ was observed in the transgenic Bt 29317 cotton compared with the conventional Jihe 321. TEM images showed aggregation of $\mathrm{CeO}_{2}$ NPs on the outer surface of chloroplasts, which resulted in the rupturing of later and release of an essential component of chlorophyll viz. $\mathrm{Zn}, \mathrm{Mg}, \mathrm{Fe}$, and $\mathrm{P}$ from xylem sap (Fig. 3).

The $\mathrm{CuO}$ uptake studies carried out on both transgenic and nontransgenic cotton showed enhanced nanoparticle concentrations in the roots of cotton plants irrespective of its type (Nhan et al. 2016b). A noticeable increase in $\mathrm{Cu}$ content was observed in the shoots and roots of the conventional cotton, when $\mathrm{CuO}$ NPs solution concentrations were increased from $200 \mathrm{mg} \cdot \mathrm{L}^{-1}$ to $1000 \mathrm{mg} \cdot \mathrm{L}^{-1}$, and this was significantly high as compared with that observed in the transgenic cotton. The TEM analysis of Ipt-cotton plant pre-exposed for 10 days to copper oxide nanoparticle concentrations (1 000 $\mathrm{mg} \cdot \mathrm{L}^{-1}$ ) showed dark dots in leaves and roots, which 
Table 2 Impact of various metal/metal oxide nanoparticles on cotton plants

\begin{tabular}{|c|c|c|c|c|c|}
\hline $\begin{array}{l}\text { Metal Oxide } \\
\text { Nanoparticles }\end{array}$ & Source/ Synthetic Method & $\begin{array}{l}\text { Cotton } \\
\text { Variety } \\
\text { Studied }\end{array}$ & $\begin{array}{l}\text { Exposure } \\
\text { Methodology }\end{array}$ & Impact on Cotton Plant & Reference \\
\hline $\begin{array}{l}\text { Cerium Oxide } \\
\left(\mathrm{CeO}_{2} \mathrm{NPs}\right) \\
\text { Size }(\mathrm{nm}) \text { : } \\
10 \pm 3.2 \\
\mathrm{Conc}(\mathrm{mg} \\
\left.\mathrm{L}^{-1}\right): 0,100 \\
500,2000\end{array}$ & Merchant & $\begin{array}{l}\text { Bt } 29317 \\
\text { \& Jihe } 321\end{array}$ & $\begin{array}{l}\text { Growth } \\
\text { chamber }\end{array}$ & $\begin{array}{l}\text { Decreased plant height, shoot and root biomass with } \\
\text { various dose treatments; } \\
\text { Decreased nutrient element content ( } \mathrm{Na}, \mathrm{Ca}, \mathrm{Zn}, \mathrm{Mg} \text {, } \\
\text { and Fe) in roots. }\end{array}$ & $\begin{array}{l}\text { Li et al. 2014; } \\
\text { Nhan et al. } \\
2015\end{array}$ \\
\hline $\begin{array}{l}\text { Silicon Dioxide } \\
\left(\mathrm{SiO}_{2} \mathrm{NPs}\right) \\
\text { Size }(\mathrm{nm}):< \\
30 \\
\text { Conc. (mg } \\
\left.\mathrm{L}^{-1}\right): 0,10 \\
100,500 \\
2000\end{array}$ & Merchant & $\begin{array}{l}\text { Bt-29312 } \\
\text { \& Jihe } 321\end{array}$ & $\begin{array}{l}\text { Growth } \\
\text { chamber }\end{array}$ & $\begin{array}{l}\text { Decreased plant height, shoot and root biomass; } \\
\text { Altered Na content in roots and Mg, Cu contents in } \\
\text { shoots; } \\
\text { Increased SOD activity, IAA concentration. }\end{array}$ & $\begin{array}{l}\text { Nhan et al. } \\
2014\end{array}$ \\
\hline \multirow[t]{2}{*}{$\begin{array}{l}\text { Copper Oxide } \\
\text { (CuO NPs) } \\
\text { Size (nm): }< \\
30 \\
\text { Conc. }(\mathrm{mg} \\
\left.\mathrm{L}^{-1}\right): 0,10 \\
200,1000\end{array}$} & Merchant & Ipt-cotton & $\begin{array}{l}\text { Growth } \\
\text { chamber }\end{array}$ & $\begin{array}{l}\text { Negatively effect on plant height, number of root } \\
\text { hairs, root length, and shoot biomass with higher } \\
\text { dose; } \\
\text { Inhibition of the synthesis of phytohormones (IAA, } \\
\text { ABA, GA, and t- ZR); } \\
\text { Increased iPA concentration, that might have resulted } \\
\text { in delayed senescence. }\end{array}$ & $\begin{array}{l}\text { Nhan et al. } \\
2016 c\end{array}$ \\
\hline & & $\begin{array}{l}\text { Bt } 29317 \\
\text { \& Jihe } 321\end{array}$ & $\begin{array}{l}\text { Growth } \\
\text { chamber }\end{array}$ & $\begin{array}{l}\text { Inhibited the growth in both transgenic and } \\
\text { conventional cottons; } \\
\text { Reduced uptake of nutrients (Mo, B, Mg, Zn, Fe, Mn); } \\
\text { Lower dose treatment improved the Bt toxin } \\
\text { expression in Bt-transgenic cotton. }\end{array}$ & $\begin{array}{l}\text { Nhan et al. } \\
2016 \mathrm{~b}\end{array}$ \\
\hline $\begin{array}{l}\text { Ferric Oxide } \\
\left(\mathrm{Fe}_{2} \mathrm{O}_{3} \mathrm{NPs}\right) \\
\text { Size }(\mathrm{nm}):< \\
50 \\
\mathrm{Conc} .(\mathrm{mg} \\
\left.\mathrm{L}^{-1}\right): 0,100 \\
1000\end{array}$ & Merchant & $\begin{array}{l}\text { Bt } 29317 \\
\text { \& Jihe } 321\end{array}$ & $\begin{array}{l}\text { Growth } \\
\text { chamber }\end{array}$ & $\begin{array}{l}\text { Inhibited plant height of Bt-transgenic cotton; } \\
\text { Promoted abundance of root hairs, and biomass of } \\
\text { conventional cotton; } \\
\text { Increased Fe, Na and K nutrients content and } \\
\text { phytohormones in the roots of Bt-transgenic cotton } \\
\text { at low } \mathrm{Fe}_{2} \mathrm{O}_{3} \mathrm{NP} \text { exposure; } \\
\text { Decreased } \mathrm{Zn} \text { contents in roots of Bt-transgenic } \\
\text { cotton; } \\
\text { Increased Bt-toxin level in roots and leaves of Bt- } \\
\text { transgenic cotton. }\end{array}$ & $\begin{array}{l}\text { Nhan et al. } \\
2016 a\end{array}$ \\
\hline $\begin{array}{l}\text { Zinc Oxide } \\
\text { (ZnO NPs) } \\
\text { Size (nm): } 2 \text { to } \\
54 \\
\text { Conc. (mg } \\
\left.L^{-1}\right): 25,50 \\
75,100,200\end{array}$ & $\begin{array}{l}\text { Using algal extract (from } \\
\text { Halimeda tuna) as reducing } \\
\text { agent }\end{array}$ & $\begin{array}{l}\text { Non- } \\
\text { transgenic }\end{array}$ & $\begin{array}{l}\text { Growth } \\
\text { chamber }\end{array}$ & $\begin{array}{l}\text { Promoted the growth, photosynthetic pigment levels, } \\
\text { biomass, and protein contents; } \\
\text { Declined MDA production; } \\
\text { Improved the activity of antioxidant defense enzymes; } \\
\text { Enhanced SOD and POX isoenzymes expression } \\
\text { levels. }\end{array}$ & $\begin{array}{l}\text { Venkatachalam } \\
\text { et al. } 2017\end{array}$ \\
\hline $\begin{array}{l}\text { Silver } \\
\text { nanoparticles } \\
\text { (AgNPs) } \\
\text { Size (nm): } 59.2 \\
\text { Conc. (mg } \\
\left.\mathrm{L}^{-1}\right): 100\end{array}$ & $\begin{array}{l}\text { Using plant extract (from } \\
\text { Pluchea sericea \& Prosopis } \\
\text { glandulosa) as reducing agent }\end{array}$ & Transgenic & $\begin{array}{l}\text { Growth } \\
\text { chamber }\end{array}$ & $\begin{array}{l}\text { AgNPs from } P \text {. glandulosa exhibited greater efficiency } \\
\text { than AgNPs from } P \text {. sericea in scaling down the } \\
\text { infection in the plants contaminated with Fusarium } \\
\text { solani. }\end{array}$ & $\begin{array}{l}\text { Abdelmoteleb } \\
\text { et al. } 2018\end{array}$ \\
\hline
\end{tabular}

confirmed the presence of $\mathrm{CuO}$ NPs (Fig. 4). The presence of dark dot in the endodermis and vascular cylinders further proved that the $\mathrm{CuO}$ NPs were first absorbed by roots (as higher concentrations of $\mathrm{CuO}$ NPs were found present in the epidermis of roots), and then were transported through xylem sap to shoots and leaves.

At a lower concentration of $\mathrm{Fe}_{2} \mathrm{O}_{3} \mathrm{NPs}\left(100 \mathrm{mg} \cdot \mathrm{L}^{-1}\right)$, there was an insignificant difference observed in the accumulation of nanoparticles in the shoots of both Bt-cotton and conventional cotton. However, with the increased concentration (1 $000 \mathrm{mg} \cdot \mathrm{L}^{-1}$ ) Bt-cotton shoots exhibited higher accumulation of iron oxide nanoparticles compared with the nontransgenic cotton (Fig. 5). At $1000 \mathrm{mg} \cdot \mathrm{L}^{-1}$ dose of $\mathrm{Fe}_{2} \mathrm{O}_{3}$ $\mathrm{NPs}$, the Fe content was also found higher in the roots of both Bt-transgenic cotton (5.3-fold) and non-transgenic cotton (2.8-fold) compared with the control groups. Further, Bttransgenic cotton displayed higher capabilities towards $\mathrm{Fe}_{2} \mathrm{O}_{3}$ 


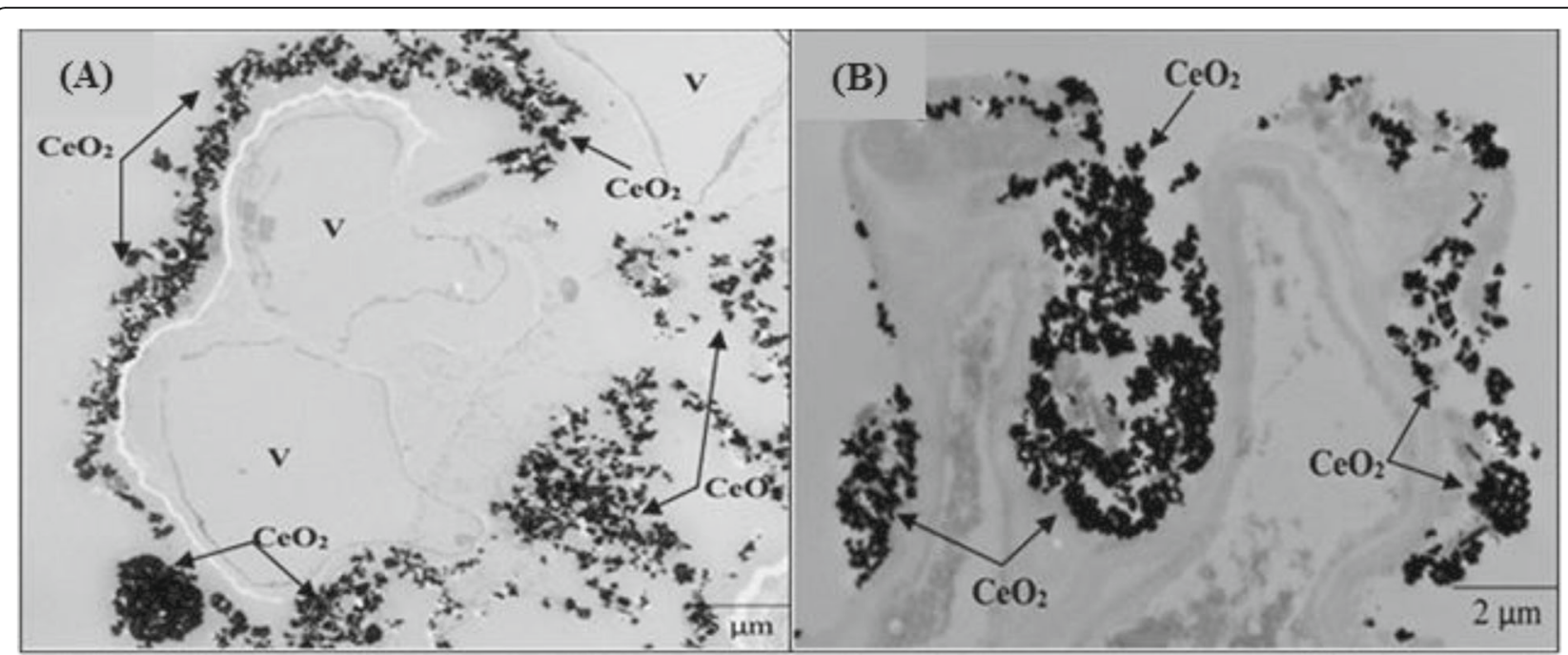

Fig. 2 Transmission electron microscopic (TEM) images of cross section of roots of conventional (a); and Bt-transgenic cottons (b) under 500 mg.L ${ }^{-1} \mathrm{CeO}_{2}$ NPs treatments. Image reproduced from Nhan et al. (2015) under a Creative Commons Attribution 4.0 International License, visit https://creativecommons.org/licenses/by/4.0/)

NPs uptake (1.27-fold) in comparison to the conventional cotton (Nhan et al. 2016a).

The TEM images of cross-sections of roots of both non-transgenic and Bt-transgenic cotton showed the presence of $\mathrm{SiO}_{2} \mathrm{NPs}$ in the form of dark dots with abundance in the epidermis and fewer in the intercellular spaces. At $2000 \mathrm{mg} \cdot \mathrm{L}^{-1} \mathrm{SiO}_{2} \mathrm{NPs}$ concentration the $\mathrm{Si}$ content observed in the Bt-transgenic roots was higher than that in the non-transgenic one, which suggests higher penetration of $\mathrm{SiO}_{2} \mathrm{NPs}$ into Bt-transgenic

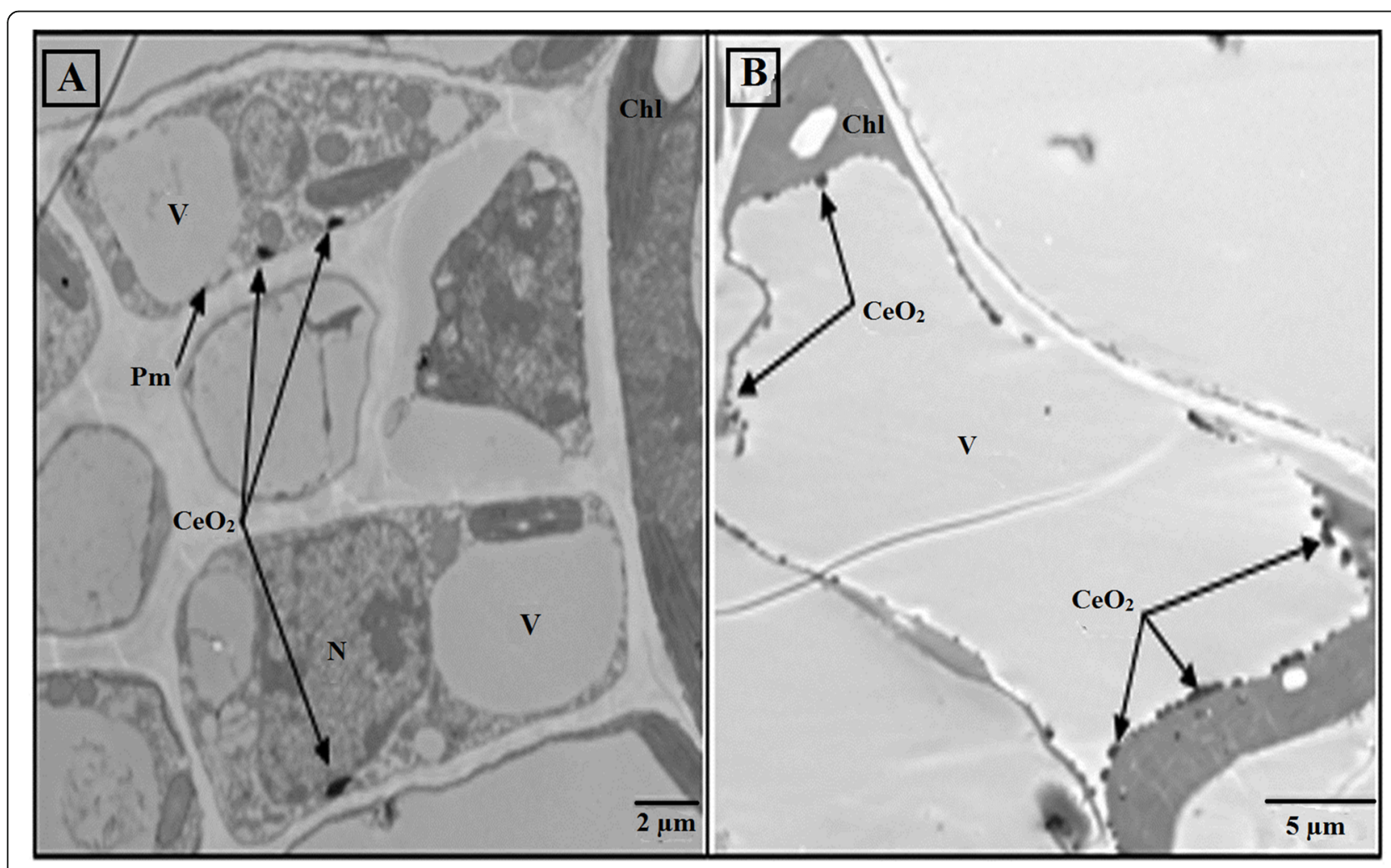

Fig. 3 TEM images of leave section of conventional cotton (a); and Bt-transgenic cotton (b) under 500 mg. $\mathrm{L}^{-1} \mathrm{CeO}_{2} \mathrm{NPs}$ treatments. Chloroplast (Chl), plasma membrane (pm), Vacuole (V). Image reproduced from Nhan et al. (2015) under a Creative Commons Attribution 4.0 International License 


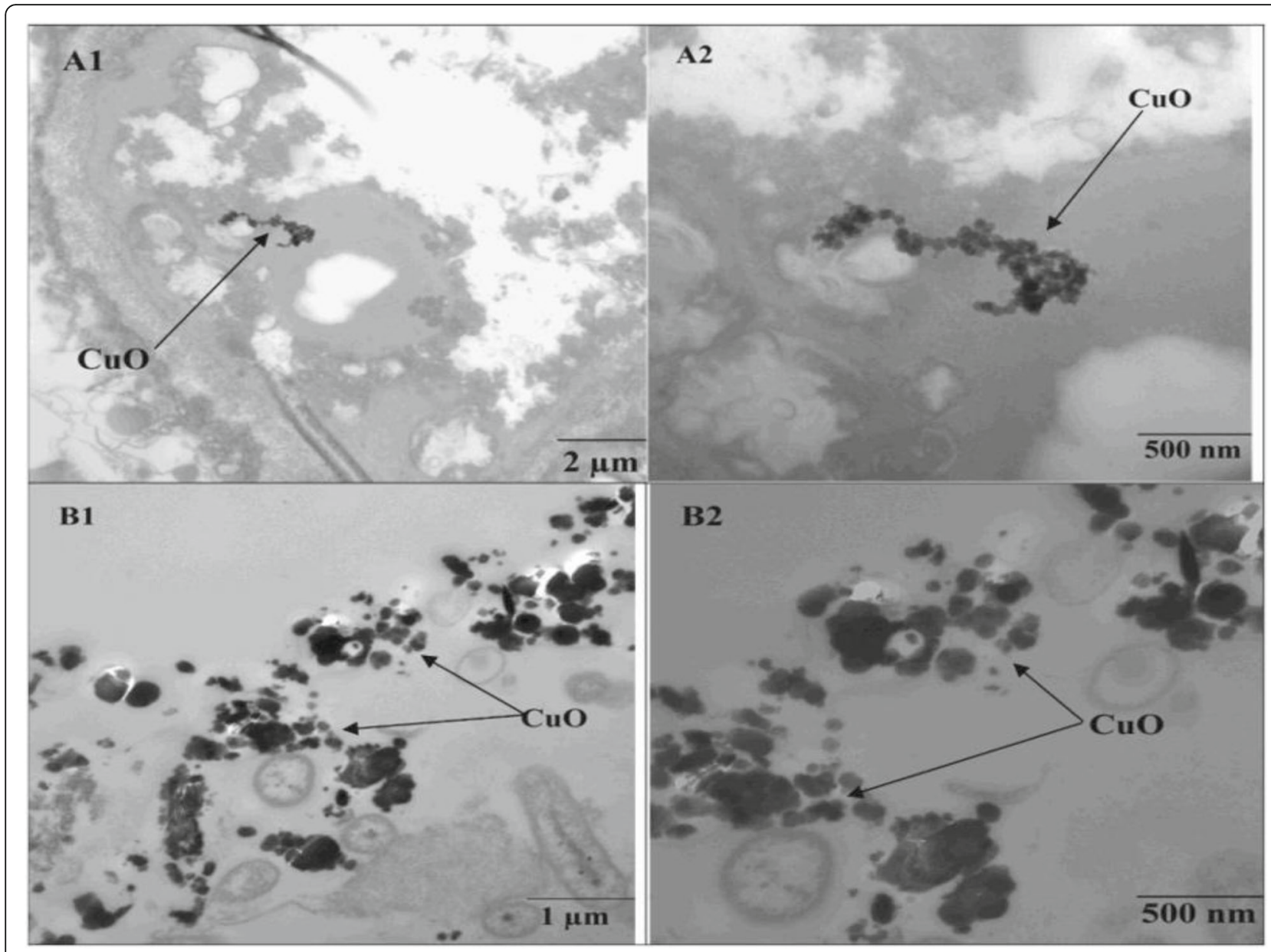

Fig. 4 TEM images of leaves (A1), (A2) and roots (B1), (B2) of Ipt-transgenic cotton after treatment with $1000 \mathrm{mg} \cdot \mathrm{L}^{-1}$ CuO NPs. (Image reproduced from Nhan et al. (2016c) under a Creative Commons Attribution 4.0 International License

cotton and have a more adverse effect on it (Nhan et al. 2014).

\section{Impact of metal oxide nanoparticles on nutrient element contents}

After water, nutrients are the most significant factors in determining crop production. Out of 16 essential elements, the fertilizers provide three $(\mathrm{N}, \mathrm{P}, \mathrm{K})$, while most of the rest of nutrients are obtained directly through either soil or atmosphere. Nanoparticles accumulation in various parts of the cotton plant affects the nutrient content levels to a significant extent. The following discussion will help us in understanding the impact of nanoparticles on the availability of nutrient elements in various parts of cotton. It has been reported that the presence of $\mathrm{CeO}_{2}$ NPs significantly decreased the nutrient element content in roots and shoots of transgenic cotton (Bt 29317) as compared with the non-transgenic (Jihe 321) (Li et al. 2014; Nhan et al. 2015). A remarkable decrease in the nutrient elements levels of $\mathrm{Zn}, \mathrm{Mg}$,
Fe, and $\mathrm{P}$ in the xylem sap was observed in $\mathrm{CeO}_{2} \mathrm{NPs}$ treated plants; however, the Mn content was significantly increased. The decrease in nutrient element concentrations in the xylem sap was more prominent in the $\mathrm{CeO}_{2}$ NPs-treated conventional cotton than that in Bttransgenic cotton plants. The $\mathrm{Ca}$ and $\mathrm{Mn}$ content in the xylem sap of both $\mathrm{CeO}_{2}$ NP-treated conventional and Bt-transgenic cotton were nearly the same and also comparable to control samples. The $\mathrm{Cu}$ content in the xylem sap of $\mathrm{CeO}_{2}$ NPs-treated transgenic cotton was on the higher side compared with the non-transgenic cotton. A significant increase in Ce content was observed in the xylem sap of both Bt 29317 and Jihe 321 with an increased concentration of $\mathrm{CeO}_{2} \mathrm{NPs}$.

Moreover, the treatment of $\mathrm{Fe}_{2} \mathrm{O}_{3} \mathrm{NPs}\left(100 \mathrm{mg} \cdot \mathrm{L}^{-1}\right)$ increased the $\mathrm{K}$ and $\mathrm{Ca}$ content of both Bt-transgenic and the non-transgenic cotton plants, but the more prominent effect was observed in the shoots and roots of the transgenic cotton plant (Nhan et al. 2016a). Increased uptake of $\mathrm{Na}$ was observed with increased $\mathrm{Fe}_{2} \mathrm{O}_{3}$ 

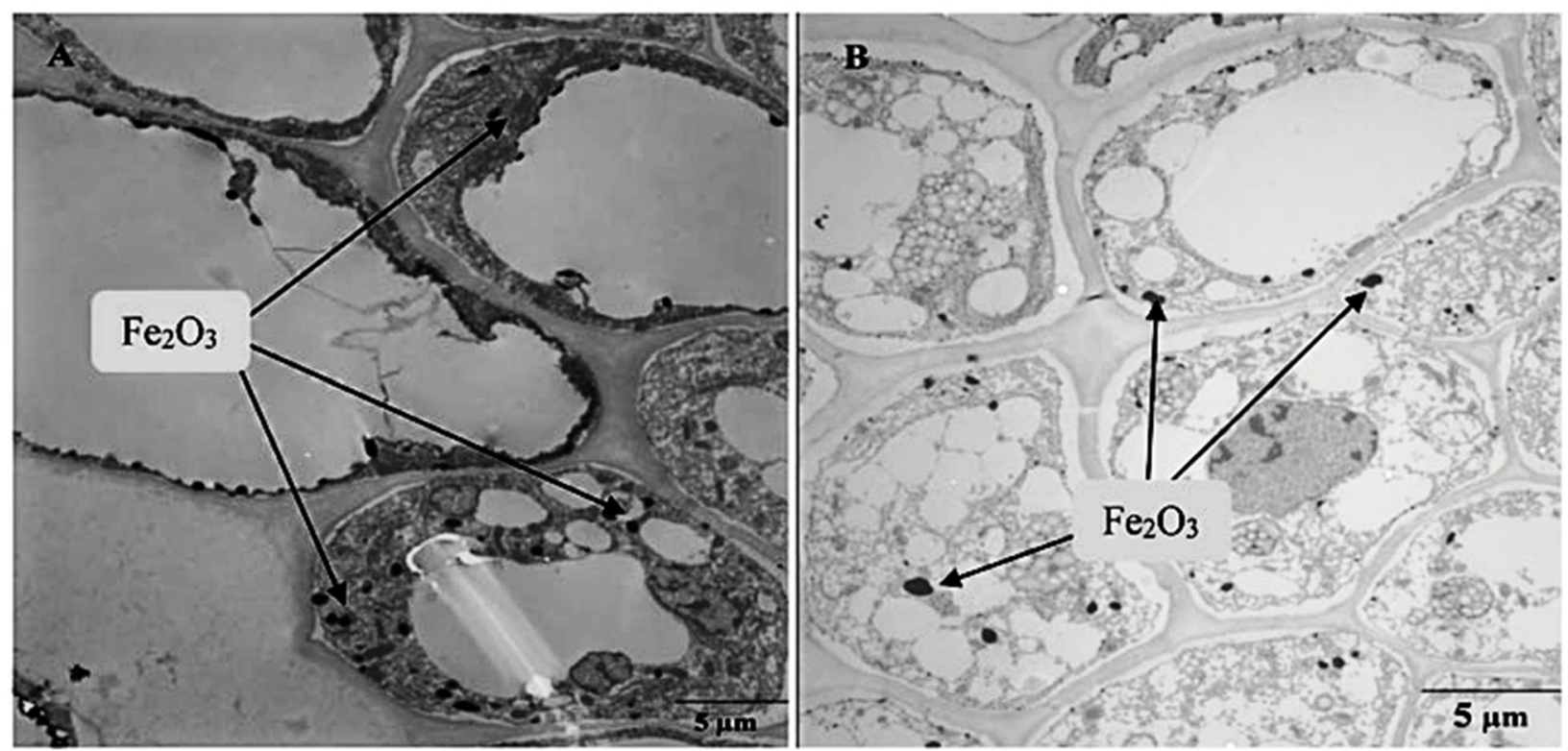

Fig. 5 TEM images of root sections of (a) non-transgenic cotton; and (b) Bt-transgenic cotton plants after treatment with $\mathrm{Fe}_{2} \mathrm{O}_{3} \mathrm{NPs}$. Image reproduced from Nhan et al. (2016a) under a Creative Commons Attribution 4.0 International License

NPs treatment (100 to $1000 \mathrm{mg} \cdot \mathrm{L}^{-1}$ ) in the Bttransgenic cotton, but $\mathrm{Na}$ uptake was altogether inhibited in the shoots of the conventional cotton. Interestingly, an entirely opposite effect was observed with the $\mathrm{Mg}$ uptake in these cotton types. The treatment of $\mathrm{Fe}_{2} \mathrm{O}_{3}$ NPs resulted in decreased concentration of $\mathrm{Mg}$ in the Bt-transgenic cotton and increased uptake of $\mathrm{Mg}$ in the conventional cotton. $\mathrm{Mn}, \mathrm{Zn}, \mathrm{P}$, and $\mathrm{Cu}$ contents in the shoots were the same in the cotton plants upon $\mathrm{Fe}_{2} \mathrm{O}_{3}$ NPs treatments irrespective of the plant type. $\mathrm{Zn}$ content was decreased while $\mathrm{Cu}$ content was increased in the roots of the Bt-transgenic cotton upon exposure to $\mathrm{Fe}_{2} \mathrm{O}_{3}$ NPs $\left(100 \mathrm{mg} \cdot \mathrm{L}^{-1}\right)$. The Bt-transgenic cotton was comprehensively found more sensitive to $\mathrm{Fe}_{2} \mathrm{O}_{3} \mathrm{NPs}$ compared with the non-transgenic cotton (Nhan et al. 2016a).

The uptakes of various nutrient content in the conventional and the transgenic cotton were differently affected with equal dose treatment of $\mathrm{CuO}$ NPs. Lower exposure of $\mathrm{CuO}$ NPs $\left(10 \mathrm{mg} \cdot \mathrm{L}^{-1}\right)$ did not affect the $\mathrm{Ca}, \mathrm{Mg}, \mathrm{Mn}, \mathrm{Mo}, \mathrm{K}, \mathrm{B}$ or $\mathrm{P}$ content in the shoots of the conventional or the transgenic cotton, but increased level (1 $\left.000 \mathrm{mg} \cdot \mathrm{L}^{-1}\right)$ resulted into enhanced nutrient uptake. CuO NPs $\left(1000 \mathrm{mg} \cdot \mathrm{L}^{-1}\right)$ treated Bttransgenic cotton exhibited a decrease in Fe and $\mathrm{Zn}$ contents, whereas an increase in both $\mathrm{Fe}$ and $\mathrm{Zn}$ content was observed at lower $\mathrm{CuO} \mathrm{NPs}\left(10 \mathrm{mg} \cdot \mathrm{L}^{-1}\right)$ treatment, and was relatively higher in the Bt-transgenic cotton $(P<0.05)$ than that in the conventional cotton. Negligible differences were observed in $\mathrm{Na}$ content in the shoots of $\mathrm{CuO}$ NPs treated conventional and transgenic cotton in comparison to the control plants, however, the $\mathrm{Na}$ content in the roots was significantly increased with increased $\mathrm{CuO}$ NPs concentrations. The $\mathrm{Na}$ content in $\mathrm{CuO}$ NPs treated $\left(1000 \mathrm{mg} \cdot \mathrm{L}^{-1}\right)$ Bt-transgenic cotton was lower than that in the conventional cotton, but higher compared with the control group. $\mathrm{CuO}$ NPs exposure (1 $000 \mathrm{mg} \cdot \mathrm{L}^{-1}$ ) did not affect the Ca, Mn, and P content, however, $\mathrm{Fe}, \mathrm{Na}$ and Mo contents alter significantly in the roots of the conventional and transgenic cotton (Nhan et al. 2016b). In Ipt-cotton, most of the nutrient contents $(\mathrm{Mg}, \mathrm{Ca}$, $\mathrm{Mn}, \mathrm{Mo}, \mathrm{B}$, and P) except $\mathrm{Zn}$ were undisturbed at a lower concentration treatment of $\mathrm{CuO} \mathrm{NPs}\left(10 \mathrm{mg} \cdot \mathrm{L}^{-1}\right)$ in roots and shoots and was reduced with a higher concentration (200, $1000 \mathrm{mg} \cdot \mathrm{L}^{-1}$ ) compared with the control (Nhan et al. 2016c). The Fe content in roots and $\mathrm{Na}$ and $\mathrm{Cu}$ content in both roots and shoots were increased, whereas $\mathrm{K}$ content in shoots and $\mathrm{Zn}, \mathrm{Ca}, \mathrm{B}$, and $\mathrm{P}$ contents in roots were significantly decreased, with enhanced exposure of CuO NPs (200, $1000 \mathrm{mg} \cdot \mathrm{L}^{-1}$ ).

$\mathrm{SiO}_{2} \mathrm{NPs}$ treated Bt-transgenic and non-transgenic cotton exhibited similar in $\mathrm{Fe}, \mathrm{Mn}, \mathrm{K}$ and $\mathrm{Zn}$ contents in the shoots and $\mathrm{Mn}, \mathrm{Zn}, \mathrm{Mg}$ and $\mathrm{Cu}$ contents in roots and was hardly shown any difference from control plants. However, the Fe content was observed high in roots of Bt-transgenic cotton than non-transgenic cotton on lower $\mathrm{SiO}_{2} \mathrm{NPs}$ treatments (10 and $100 \mathrm{mg} \cdot \mathrm{L}^{-1}$ ), and exactly opposite was observed at higher $\mathrm{SiO}_{2} \mathrm{NPs}^{-1}$ treatments $\left(500\right.$ and $\left.2000 \mathrm{mg} \cdot \mathrm{L}^{-1}\right)$. The contents of $\mathrm{Cu}, \mathrm{K}$, and $\mathrm{Na}$ were higher in the roots of Bt-transgenic cotton at various concentrations of treatment, but significantly decreased in shoots. This reflects the greater tendencies of nutrient element absorptions by treated Bt-transgenic cotton, but poor transportation of the same to the 
shoots. Further, $\mathrm{SiO}_{2}$ NPs treatment had insignificant effects on the $\mathrm{Mn}, \mathrm{K}, \mathrm{Na}, \mathrm{Cu}, \mathrm{Zn}$, and $\mathrm{Ca}$ contents in the xylem sap of both non-transgenic and $\mathrm{Bt}$ transgenic cotton, but concentrations differ remarkably in the xylem sap of two cotton plants. Fe and $\mathrm{Mg}$ transportations were geared-up by the presence of $\mathrm{SiO}_{2}$ NPs in the xylem sap of both non-transgenic and Bt-transgenic cotton, but concentrations of both nutrient elements were nearly same in the xylem sap of the genetically-modified and conventional cotton (Nhan et al. 2014).

\section{Impact of metal oxide nanoparticles on phytohormone concentrations}

Plant growth hormones are chemical substances that regulate the various physiological activities in a plant viz. cell elongation and cell division, metabolism, stress relief, seed germination, and senescence, etc. There are mainly four plant growth hormones viz. Auxins (indole3-acetic acid, IAA), cytokinins (trans-zeatinriboside, $\mathrm{t}$ ZR), gibberellins (Gibberellic acid, GA), and abscisic acid (ABA) that regulate the growth and harmony in plants. The distribution and accumulation of various metal oxide-based nanoparticles (MNPs) in the different plant parts may pose beneficial and adverse impacts on the synthesis and regulation of these phytohormones.

$\mathrm{CeO}_{2}$ NPs exposures had different effects on hormones in different parts of Bt-transgenic and conventional cotton plants. At $500 \mathrm{mg} \cdot \mathrm{L}^{-1} \mathrm{CeO}_{2} \mathrm{NP}$ exposure did not alter the auxin hormone (indole-3-acetic acid, IAA) concentrations in the leaves and roots of Bttransgenic cotton and the control groups, but it was found significantly higher (1.29 times) in the leaves of the conventional cotton compared with the control plants. In contrast, the roots of $\mathrm{CeO}_{2} \mathrm{NPs}$ treated $\mathrm{Bt}$ transgenic cotton exhibited higher IAA levels as compared with the conventional cotton, but comparatively lower than the control plants. The t-ZR content in the leaves and roots of $\mathrm{CeO}_{2}$ NPs exposed Bt-transgenic cotton was not perturbed, however, a significant decrease in t-ZR levels were observed in the leaves (76.6\%) and roots (91.3\%) of conventional cotton as compared with the control groups. The GA content in the leaves of $\mathrm{CeO}_{2}$ NP treated conventional cotton was higher than that in Bt-transgenic cotton $(P<0.05)$. These results showed greater sensitivity of the conventional cotton towards phytohormones under $\mathrm{CeO}_{2} \mathrm{NPs}$ treatment.

The abscisic acid (ABA) contents in the roots of nontransgenic cotton were maximum $\left(72.98 \mathrm{ng}^{-1} \mathrm{~g}^{-1}(\mathrm{FW})\right)$ at $500 \mathrm{mg} \cdot \mathrm{L}^{-1}$, and minimum $\left(65.57 \mathrm{ng} \cdot \mathrm{g}^{-1}(\mathrm{FW})\right)$ at 2000 $\mathrm{mg} \cdot \mathrm{L}^{-1} \mathrm{SiO}_{2} \mathrm{NPs}$ treatments, and were evidently higher than Bt-transgenic cotton at the control treatment, but exactly opposite effect was observed at 100 and $2000 \mathrm{mg} \cdot \mathrm{L}^{-1} \mathrm{SiO}_{2} \mathrm{NP}$ treatments in the former cotton plant (Fig. 6).

Moreover, the exogenous application of $\mathrm{Fe}_{2} \mathrm{O}_{3}$ NPs to different concentrations had a negative effect on the root hormone contents in both Bt-transgenic and conventional cotton, and hence retarded the plant growth and development (Nhan et al. 2016a). The ABA and GA contents in the leaves were decreased in the $\mathrm{Fe}_{2} \mathrm{O}_{3}$ NP-treated conventional cotton as compared with the transgenic one which displayed an increase in GA content in the leaves of Bt-transgenic cotton with no influence on ABA levels. Additionally, the exposure of $\mathrm{Fe}_{2} \mathrm{O}_{3} \mathrm{NPs}\left(100 \mathrm{mg} \cdot \mathrm{L}^{-1}\right)$ to

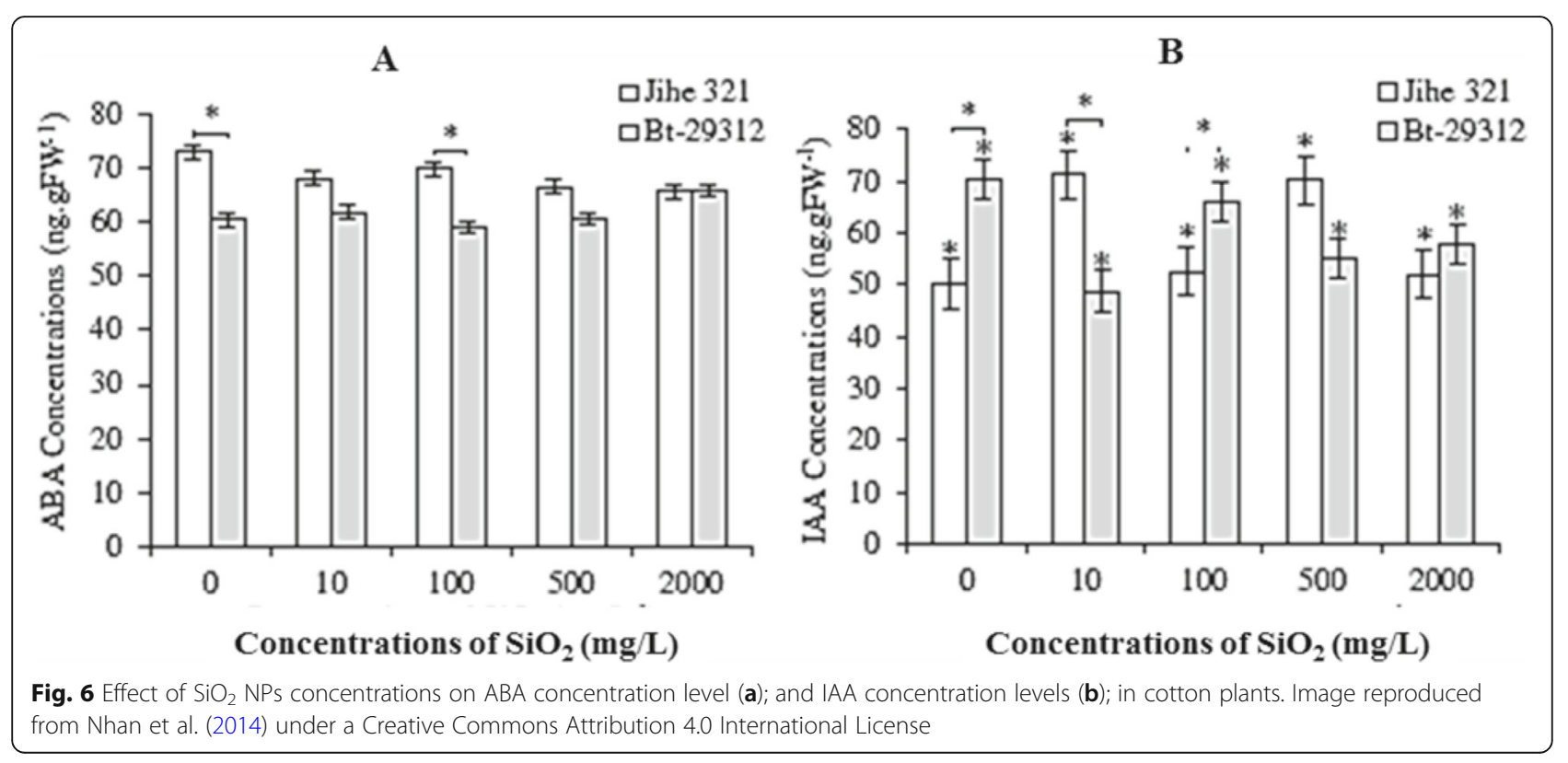


the roots of Bt-transgenic cotton resulted in enhancement of all phytohormone concentrations, but with the opposite effect in the non-transgenic cotton.

Furthermore, various $\mathrm{CuO}$ NPs treatments resulted in elevated hormonal levels (IAA, ABA, and GA), in both conventional and transgenic cotton plants relative to control groups, with the more prominent effects observed in the conventional cotton plants. Although, the t-ZR content was slightly decreased with $\mathrm{CuO} \mathrm{NP}$ treatment in the conventional cotton plant. However, the t$\mathrm{ZR}$ and IAA hormone contents were comparatively higher in the transgenic roots than those in the control groups, when treated with varying concentrations of $\mathrm{CuO}$ NPs (Nhan et al. 2016b). In Ipt-cotton, $\mathrm{CuO}$ NPs treatments with lower doses, i.e., 10 and $200 \mathrm{mg} \cdot \mathrm{L}^{-1}$, caused a decrease in the level of IAA content in leaves, whereas an increase was observed in the roots of treated cotton plants compared with the control groups (Nhan et al. 2016c). The $\mathrm{CuO}$ NPs influenced inhibited production of IAA in leaves was in concordance with diminished plant height and biomass. The ABA content in the leaves and roots showed its direct correlation with the dose of $\mathrm{CuO}$ NPs treatment. The GA synthesis was inhibited in leaves, and was promoted in roots on treatment with $\mathrm{CuO}$ NPs. The t-ZR hormone in the leaves and roots was unaltered at lower dose treatments of $\mathrm{CuO}$ NPs, but differs significantly with higher concentration of $\mathrm{CuO}$ NPs from that in controls.

\section{Impact of metal oxide nanoparticles on the enzyme activities}

Recent studies showed that various metal oxide nanoparticles at different levels play a significant role in detoxifying the reactive oxygen species by stimulating antioxidative machinery in both conventional and transgenic cotton.

When cotton was treated with $\mathrm{ZnO}$ NPs at different concentrations, the SOD activity in plants treated with 75 $\mathrm{mg} \cdot \mathrm{L}^{-1}$ was increased up to $267.8 \%$ compared with the untreated plant, while it decreased at higher doses of $\mathrm{ZnO}$ NPs (Venkatachalam et al. 2017). Subsequently, slight improvement was noticed in CAT activity (106.9\%) at 25 $\mathrm{mg} \cdot \mathrm{L}^{-1}$, and which declined significantly with an increasing concentration of $\mathrm{ZnO}$ NPs. Along with SOD and CAT, the POX activity was also improved by $174.5 \%$ under $100 \mathrm{mg} \cdot \mathrm{L}^{-1} \mathrm{ZnO}$ NPs application, however, it decreased at higher doses of the treatment. Such concomitant decreased activity of SOD, CAT, and POX enzyme with a higher dose of ZnO NPs in cotton leaves with a decreased level of malondialdehyde (MDA) content suggested that the cotton augments antioxidant enzymes level to alleviate the accumulated $\mathrm{H}_{2} \mathrm{O}_{2}$. Additionally, $\mathrm{ZnO}$ NPs exposure $\left(200 \mathrm{mg} \cdot \mathrm{L}^{-1}\right)$ caused a significant decline in the MDA content (73.8\%) in the leaves of treated cotton compared with the control. Although, boosting of SOD and POX activities in ZnO NPs treated plants were found successful to neutralize free radical-mediated oxidative damage in G. hirsutum.

Native PAGE was performed to analyze the expression pattern for SOD and POX isozymes in the cotton leaves treated with ZnO NPs (Venkatachalam et al. 2017). For SOD, 2 isoforms were noticed in the isozyme banding pattern, where SOD isoform 1 was visible, while the SOD isoform 2 was absent in the leaves exposed with higher ZnO NPs doses (100 and $200 \mathrm{mg} \cdot \mathrm{L}^{-1}$ ). Like SOD, two isoforms were also observed for POX isoenzyme, among them, POX isoform 2 bands were clearly observed in ZnO NP treated plants, although it was absent in the control. Interestingly, expression of POX isoform 1 was found 2-3 folds higher in leaf tissue treated with higher doses of NPs over the control. Here, the interesting fact to be noted was that, the level of SOD and POX isoenzymes expression was on a par with the quantitative analysis results of the respective enzymes.

Additionally, no significant differences were observed in POD and CAT activities between Bt and conventional cotton cultivars, and even between the treated and the control plants exposed to $\mathrm{SiO}_{2} \mathrm{NP}$. At higher $\mathrm{SiO}_{2} \mathrm{NP}$ treatment (2 $000 \mathrm{mg} \cdot \mathrm{L}^{-1}$ ), the CAT activities were decreased from $9.15 \mu \mathrm{g} \cdot \mathrm{mL}^{-1}$ to $4.63 \mu \mathrm{g} \cdot \mathrm{mL}^{-1}$ in the roots of non-transgenic cotton, however, in the Bt-cotton, these were declined from $7.99 \mu \mathrm{g} \cdot \mathrm{mL}^{-1}$ to $3.70 \mu \mathrm{g} \cdot \mathrm{mL}^{-1}$. This study clearly indicated that the CAT activities were negatively affected by $\mathrm{SiO}_{2} \mathrm{NPs}$ in the roots of both $\mathrm{Bt}$ and conventional cotton. Unlike CAT, Bt and conventional cotton showed higher POD activities with increased $\mathrm{SiO}_{2}$ NPs concentration up to 500 $\mathrm{mg} \cdot \mathrm{L}^{-1}$ and followed by declined at $2000 \mathrm{mg} \cdot \mathrm{L}^{-1}$, in comparison to the controls, suggesting that the POD activities were triggered by $\mathrm{SiO}_{2} \mathrm{NPs}$ with lower concentrations (> $500 \mathrm{mg} \cdot \mathrm{L}^{-1}$ ) in both kinds of cotton. Additionally, nontransgenic and Bt-cotton showed significantly different SOD activities between the control and NPs treatments. The maximum SOD activity was observed at 10 and $500 \mathrm{mg} \cdot \mathrm{L}^{-1} \mathrm{SiO}_{2}$ NPs treatment for both non-transgenic $\left(58.98 \mu \mathrm{g} \cdot \mathrm{mL}^{-1}\right)$ and Bt-cotton $\left(79.51 \mu \mathrm{g} \cdot \mathrm{mL}^{-1}\right)$, while lesser activity was observed at $0.0 \mathrm{mg} \cdot \mathrm{L}^{-1}$ (the control treatment), 100 and $2000 \mathrm{mg} \cdot \mathrm{L}^{-1}$ $\mathrm{SiO}_{2}$ NPs treatments (Fig. 7) (Nhan et al. 2014).

There were insignificant differences between POD and SOD activities, observed in roots and leaves, respectively, in Bt or conventional cotton and the control samples, when treated with $\mathrm{CeO}_{2}$ NPs. Bt-transgenic cotton showed significantly higher POD activity in the leaves than that in conventional cotton $(P<0.05)$, when exposed to $500 \mathrm{mg} \cdot \mathrm{L}^{-1} \mathrm{CeO}_{2} \mathrm{NPs}$ ( $\mathrm{Li}$ et al. 2014). However, the insignificant difference was shown by SOD in the leaves as well as roots of Bt-cotton, and the leaves of $\mathrm{CeO}_{2}$ NP-treated conventional cotton and the control plants, while SOD activity in roots of Bt-cotton was 

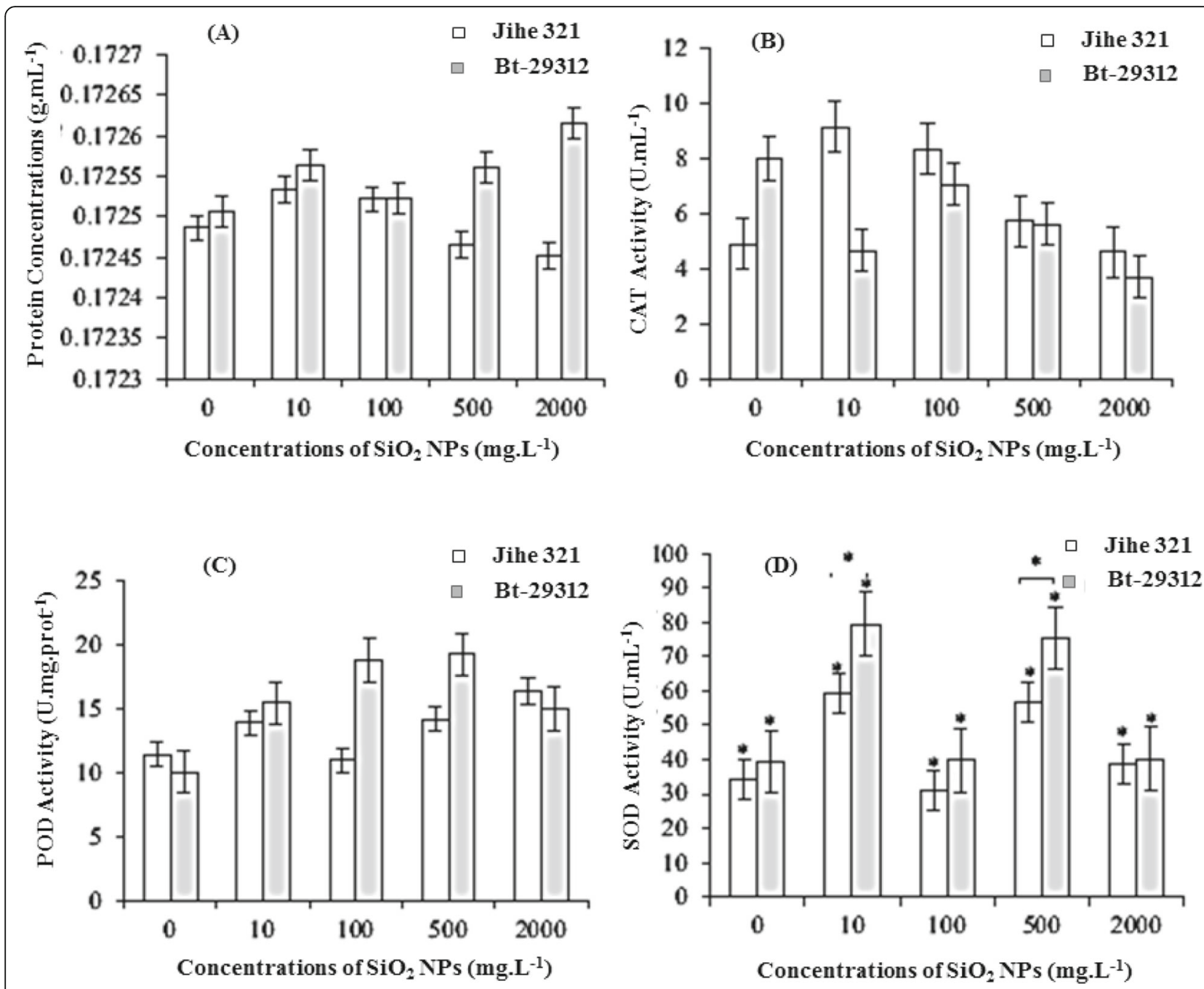

Fig. 7 Effects of $\mathrm{SiO}_{2}$ NPs concentrations on the protein concentrations (a); CAT activity (b); POD activity (c); and SOD activity (d) of cotton plants. Image reproduced from Nhan et al. (2014) under a Creative Commons Attribution 4.0 International License

significantly lesser $(P<0.05)$ than untreated conventional cotton. Although, SOD activity under $\mathrm{CeO}_{2}$ treatment in root of the conventional and Bt-cotton plants showed no significant difference.

\section{Impact of metal oxide nanoparticles on Bt-toxin expression}

The Bt toxins defend transgenic cotton against biotic stress resulting from vandalization by other living organisms like viruses, fungi, parasites, bacteria, insects, weeds, etc. The presence of metal oxide nanoparticles considerably influences the levels of Bt toxins in the different parts of the cotton plant and thus is directly linked to growth and biomass production of cotton.

Bt toxin levels were improved with lower dose treatment of $\mathrm{CuO}$ NPs $\left(10 \mathrm{mg} \cdot \mathrm{L}^{-1}\right)$ in the leaves and roots of Bt-transgenic cotton and were significantly higher than those observed in the control plants (Nhan et al. 2016b). However, the remarkably decreased Bt toxin expression was observed with increased exposure of $\mathrm{CuO}$ NPs (1 $000 \mathrm{mg} \cdot \mathrm{L}^{-1}$ ) and was assigned to the absorption of $\mathrm{Bt}$ toxin protein by $\mathrm{CuO}$ NPs present in large amounts.

$\mathrm{Fe}_{2} \mathrm{O}_{3}$ NPs exposure to lower concentration dose (100 $\mathrm{mg} \cdot \mathrm{L}^{-1}$ ) explicitly enhanced Bt toxin levels in leaves $\left(845.89 \mathrm{ng} \cdot \mathrm{g}^{-1}\right)$ and roots $\left(886.94 \mathrm{ng} \cdot \mathrm{g}^{-1}\right)$ of Bt cotton, which was higher by manifolds than their respective control groups (Fig. 8). The treatment of a higher dose of $\mathrm{Fe}_{2} \mathrm{O}_{3} \mathrm{NPs}\left(1000 \mathrm{mg} \cdot \mathrm{L}^{-1}\right)$ resulted in decreased expression level of $\mathrm{Bt}$ toxin in leaves and roots, but was still higher than in control groups (Nhan et al. 2016a).

Bioengineered phycomolecule coated ZnO NPs (200 $\mathrm{mg} \cdot \mathrm{L}^{-1}$ ) induced enhancement in the rate of formation of photosynthetic pigments, i.e., chlorophyll-a, 134.7\%; chlorophyll-b, 132.6\%; and carotenoids, $160.1 \%$ in cotton 


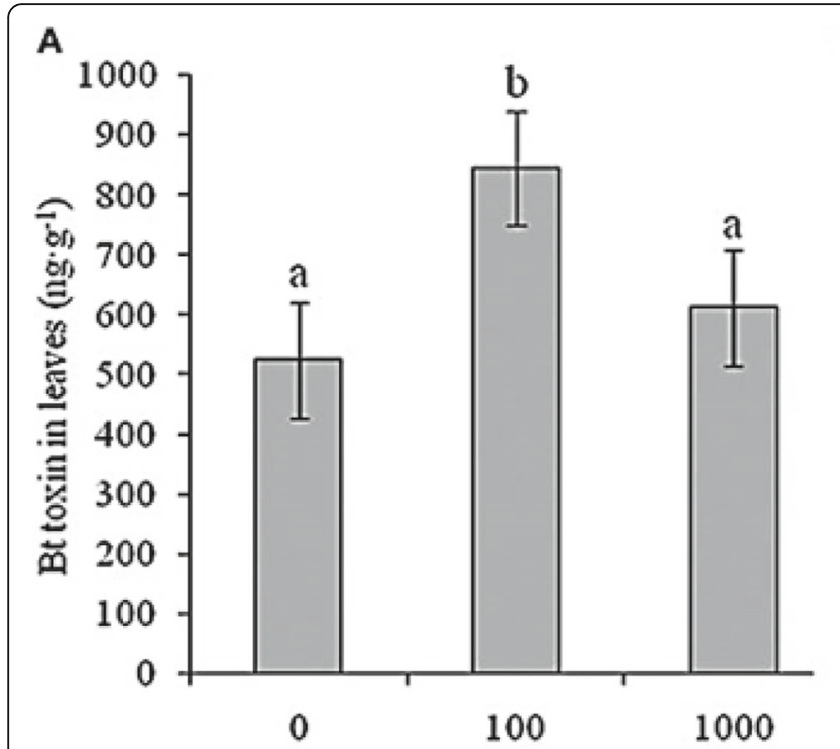

B

Concentrations of $\mathrm{Fe}_{2} \mathrm{O}_{3} \mathrm{NPs}(\mathrm{mg} / \mathrm{L})$

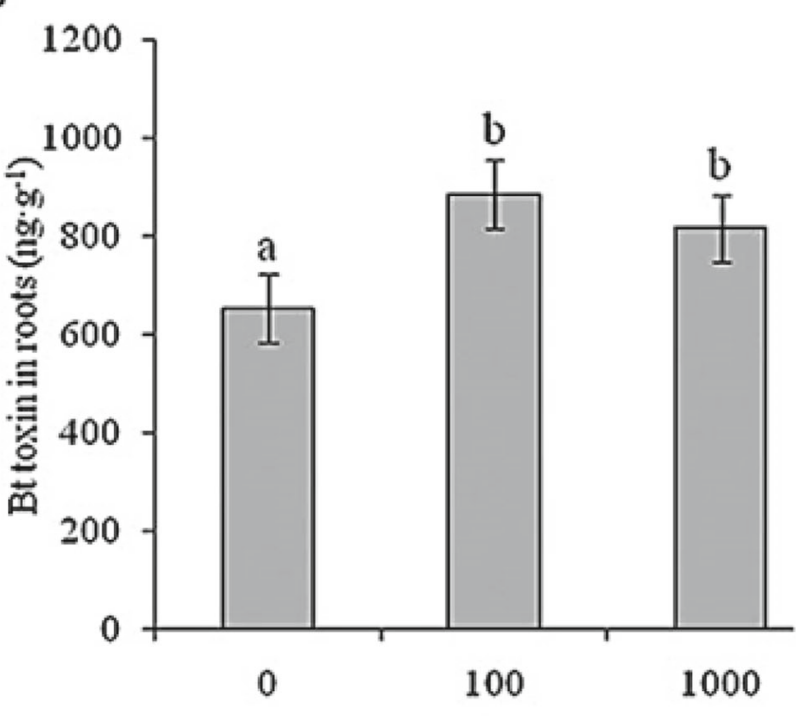

Concentrations of $\mathrm{Fe}_{2} \mathrm{O}_{3} \mathrm{NPs}(\mathrm{mg} / \mathrm{L})$

Fig. 8 Effect of $\mathrm{Fe}_{2} \mathrm{O}_{3} \mathrm{NPs}$ concentrations on the Bt toxin levels in leaves (a); and roots (b) of cotton plants. Image reproduced from Nhan et al. (2016a) under a Creative Commons Attribution 4.0 International License

(Venkatachalam et al. 2017). RAPD-DNA fingerprinting analysis is used as a powerful tool to detect the genomic changes/alterations that occurred in the plants. $\mathrm{ZnO}$ NPs treatment did not change any banding pattern excluding DNA amplicon intensity. Ten out of 80 primers showed distinct DNA patterns, but only 4 primers showed DNA fingerprinting bands with changed intensity under the effect of $\mathrm{ZnO}$ NPs. The ineffectiveness $\mathrm{ZnO}$ NPs on the cotton genome could be either because the formation of $\mathrm{ZnO}$ nano complexes capped with different growth-promoting factors, or the $\mathrm{Zn}$ ions becomes available by phycomolecule-coated $\mathrm{ZnO}$ NPs to dividing cells without harming DNA of the plants.

Fusarium wilt caused by Fusarium solani, is an important disease that occurs in cotton plants in various countries (Gonzalez-Soto et al. 2015). The AgNPs were synthesized using leaf extract of Prosopis glandulosa and P. sericea and were diluted at $100 \mathrm{mg} \cdot \mathrm{L}^{-1}$ with demineralized water (Abdelmoteleb et al. 2018). The cotton plants were grown up to seedlings, developed few roots and were transferred to infested soil with $F$. solani TICA04. The AgNPs were applied weekly and caused a curtailment of fungal growth after 30 days of treatment. In terms of limiting infection (antifungal activity) in the roots of F. solani infected plants AgNPs from P. glandulosa were found more potent. Additionally, the application of these AgNPs from P. sericea and P. glandulosa showed a significant increase of stomata conductance (gs), optimum quantum efficiency $\left(\mathrm{F}_{\mathrm{v}} / \mathrm{F}_{\mathrm{m}}\right)$, and the number of lateral roots in transgenic cotton, when compared with the control after 30 days of NPs exposure.

\section{Impact of metal oxide nanoparticles on plant height and biomass}

Different concentrations of various nanoparticles and their time of exposure have both positive and negative impacts on various growth parameters, viz., plant height, root length, root and shoot biomass. The growth of cotton plants was increased with the increasing dose of $\mathrm{ZnO}$ NPs. The growth tolerance index was increased to $115.2 \%$ \& $130.6 \%$ for root and shoot, respectively, at $200 \mathrm{mg} \cdot \mathrm{L}^{-1}$ $\mathrm{ZnO}$ concentration (Fig. 9). No toxicity was found even with a high dose of treatment. For different concentrations of $\mathrm{ZnO}$ (25 to $200 \mathrm{mg} \cdot \mathrm{L}^{-1}$ ), fresh and dry weight was improved from 113.7 to $125.4 \%$ \& 115.7 to $131 \%$, respectively (Venkatachalam et al. 2017).

On the contrary, the decrease in biomass and plant height of conventional and transgenic cotton was observed with increased proportions of $\mathrm{SiO}_{2}$ NPs (500, $\left.1000,2000 \mathrm{mgL}^{-1}\right)$. No significant decrease was detected up to $500 \mathrm{mg} \cdot \mathrm{L}^{-1}$, but the dose treatment of $2000 \mathrm{mg} \cdot \mathrm{L}^{-1}$ resulted in lessen plant height for both non-transgenic and transgenic cotton (Nhan et al. 2014).

The treatment of various concentrations of $\mathrm{Fe}_{2} \mathrm{O}_{3}$ NPs showed no significant difference in plant height between the conventional and Bt-cotton plants of the control 

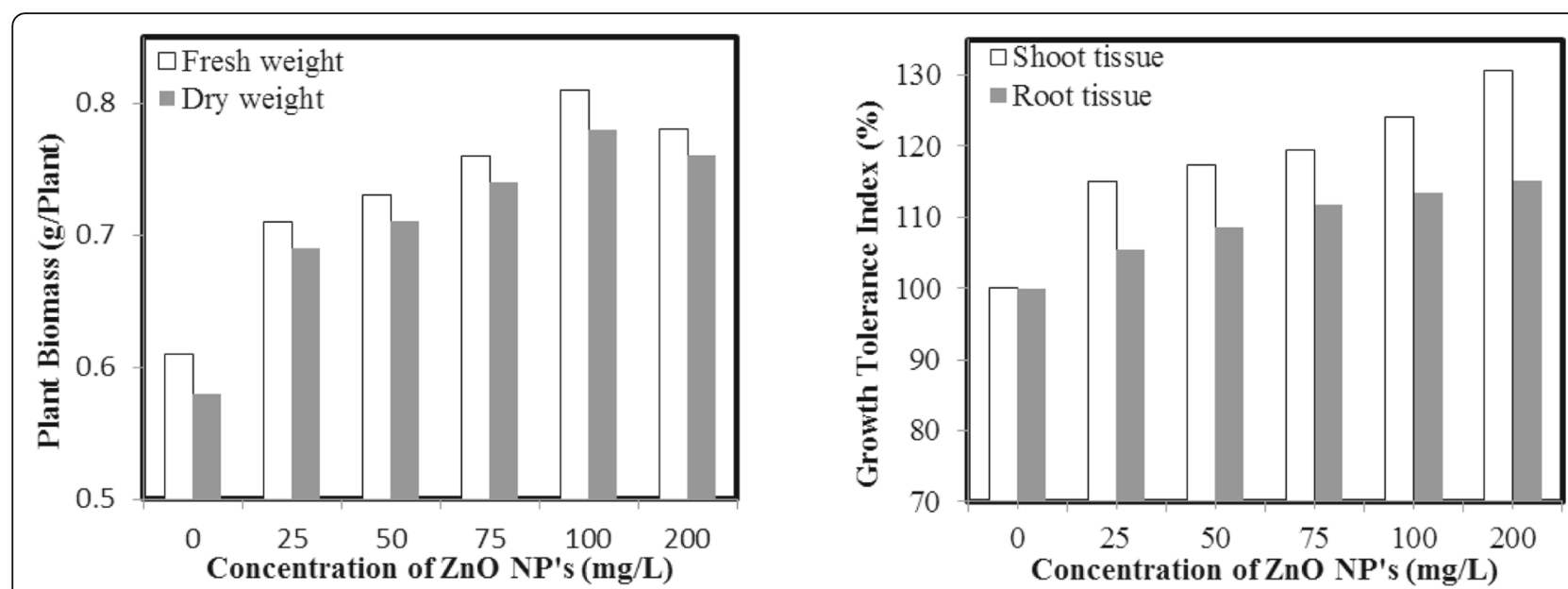

Fig. 9 Effect of ZnO NPs concentrations on the growth tolerance index of root and shoot tissue (a); and plant biomass (b) of cotton plant

groups. However, in conventional cotton, the enlargement in the root (length, hair) with the enhancement in root biomass was observed (30.8 to $41.2 \%$ ) in comparison to the control. But in transgenic cotton, there was no significant change observed in plant height, root (length, hair, \& biomass) or shoot biomass (Nhan et al. 2016a).

In both conventional and transgenic cotton, the growth parameters were negatively affected by the increasing concentration of $\mathrm{CuO}$ NPs accounted for the toxic effect of NPs. The harmful effect on the root growth was more prominent than the shoot growth and was attributed to greater accumulation of $\mathrm{CuO}$ NPs in the root. More than $50 \%$ reduction in root biomass (hair, length) was observed at higher dose treatment (1 000 $\left.\mathrm{mg} \cdot \mathrm{L}^{-1}\right)$. Plant height, root length, root and shoot biomass were not much affected at low concentrations of $\mathrm{CuO}$ NPs $\left(10 \mathrm{mg} \cdot \mathrm{L}^{-1}\right)$ than those at high concentration (200 \& $\left.1000 \mathrm{mg} \cdot \mathrm{L}^{-1}\right)$. CuO NPs caused a significant reduction in root lengths of 45.79 and $42.80 \%$ at higher concentrations of 200 and $1000 \mathrm{mg} \cdot \mathrm{L}^{-1}$, respectively (Nhan et al. 2016b).

The treatments of the transgenic and non-transgenic cotton plants with different concentrations of $\mathrm{CeO}_{2} \mathrm{NPs}$ (100, 500, $\left.2000 \mathrm{mg} \cdot \mathrm{L}^{-1}\right)$ had no effect on plant height and shoot biomass as compared with the control. But a significant difference in plant biomass was obtained between both types at higher concentrations (500 and $\left.2000 \mathrm{mg} \cdot \mathrm{L}^{-1}\right)$. Only the root biomass of transgenic cotton was reduced at 100 and $500 \mathrm{mg} \cdot \mathrm{L}^{-1}$ concentrations of $\mathrm{CeO}_{2} \mathrm{NPs}$ (Li et al. 2014). The exposure methodology and impact of various metal/metal oxide nanoparticles on different cotton varities have been summarized in Table 2.

\section{Discussion and future directions}

Advances in the field of biotechnology helped in the development of new cotton species (e.g., Bt 29317, Ipt-cotton) with better characteristics than their conventional counterpart (e.g., Jihe 321). To some extent, this facilitated to achieve goals like better production, disease, and stress resistance, etc. Further, the assistance was provided by nanotechnology in the form of metal or metal-oxide nanoparticles that helped in the improvement of physiological parameters in various plant parts like leaves, shoots, and roots. These nanoparticles were having easy access to the various parts of the cotton plant through its transportation system. However, it has been found that fewer NPs are being transported from roots to shoots in Bt cotton as compared with the conventional cotton, indicating the difficulty in translocation through vascular tissues which is an energy intensive process. The possible mechanism behind this could be the more energy consumption in the formation of Bt-toxin as compared with the transportation of NPs (Zhao et al. 2012). This was evident from the TEM images of the area of cross-sections of leaves, shoots, and roots, etc., and displayed an accumulation of nanoparticles in the form of black dots. The presence of these nanoparticles affected the availability of nutrient elements in different plant parts, and thus altered the plant growth parameters like height and biomass. A correlation was found between the nutrient content/growth parameters and the altered dose concentration of nanoparticles. Some nanoparticles were more effective with lower dose concentrations; however, others displayed their potency with higher values of dose treatments. Comparative studies were also performed to explore the concentration-dependent effect of nanoparticles on the growth parameters of both transgenic and conventional cotton. Some growth parameters were significantly affected by the increased/decreased concentrations 
of the nanoparticles in transgenic cotton; while the same were remain unaltered in the conventional plants or vice versa. This suggested that various nanomaterials have different effects on different cultivars. However, the mechanism underlying this difference is unknown so far and thus, provide a wider scope for further studies in this extensive area. Growth parameters like phytohormone concentrations, cellular enzyme activities and Bt-toxin levels were effectively maintained via careful applications of different concentrations of nanoparticles. This comprehensive review will help the researchers in selecting the correct dose concentrations of the selected nanoparticle to achieve the desired targets in the selected cotton species. The limitations of the studied nanoparticles, which are discussed in this literature review can be easily overcome by experimenting with varied concentrations of other metal or metal oxide nanoparticles, and their effects on the physiological parameters of cotton plants can be explored. The ultimate solution to the problem of improvement of cotton fiber yield can only be realized via exploring the impacts of various nanoparticles on cotton plants.

\section{Conclusion}

Bt-transgenic and conventional cotton have a great affinity to metal and metal oxide nanoparticles (MNPs) as evident from their uptake and distribution into various plant parts. Plant growth factors, viz., nutrient plant content, phytohormone levels, cellular enzyme activities, Bt toxin expression, etc., exhibited altered sensitivities towards varied dose treatments of different NPs. Some NPs significantly affected the plant growth parameters in roots, while others showed their sensitivities in leaves and shoots, but to different extents. The beneficial effects of these nanoparticles can be explored to accomplish the necessities of agricultural fields; however, the first emphasis should be laid on understanding the mechanism of interaction between various growth parameters and NPs. Meticulous usage of these NPs may ascertain fruitful improvements in controlling morphological variations, and thus the overall growth and production of cotton fibers.

\section{Abbreviations \\ Bt: Bacillus thuringiensis; NPs: Nanoparticles; QD: Quantum dot; SOD: Superoxide dismutase; POD: Peroxidase; CAT: Catalase; CNT: Carbon nanotube; DNA: Deoxyribose nucleic acid; miRNA: MicroRNA; ICP- MS: Inductively coupled plasma mass spectrometry; TEM: Transmission electron microscopy; IAA: Indole-3-acetic acid; t-ZR: Trans-zeatinriboside; GA: Gibberellic acid; ABA: Abscisic acid; MNP: Metal oxide nanoparticle; GR: Glutathione reductase; DHAR: Dehydroascorbate reductase; MDA: Malondialdehyde; POX: Proline oxidase; PAGE: Polyacrylamide gel electrophoresis; RAPD: Random amplified polymorphic DNA}

\section{Acknowledgments}

The authors of this manuscript are thankful to Akal University for providing financial support and research facilities.
Authors' contributions

All authors contributed equally in collecting and conceptualizing the literature material related to the manuscript topic, helping shape the manuscript and providing critical feedback. The author(s) read and approved the final manuscript.

\section{Funding}

Not applicable.

Availability of data and materials

Not applicable.

\section{Declarations}

Ethics approval and consent to participate

Not applicable.

\section{Consent for publication}

All data used for writing the manuscript has been cited with proper references. Images used for the review manuscript are cited with reference under a Creative Commons Attribution 4.0 International License.

\section{Competing interests}

The authors have no competing interests.

\section{Author details}

${ }^{1}$ Department of Chemistry, Akal University, Talwandi Sabo, Bathinda, Punjab 151302, India. 'Department of Botany, Akal University, Talwandi Sabo, Bathinda, Punjab 151302, India. ${ }^{3}$ Indian Agricultural Statistics Institute, Delhi, India.

Received: 25 December 2020 Accepted: 27 April 2021

Published online: 02 June 2021

\section{References}

Abdelmoteleb A, Gonzalez-Mendoza D, Valdez-Salas B, et al. O. Inhibition of Fusarium solani in transgenic insect-resistant cotton plants treated with silver nanoparticles from Prosopis glandulosa and Pluchea sericea. Egypt J Biol Pest Cont. 2018;28(1):4. https://doi.org/10.1186/s41938-017-0005-0.

Abigail EA, Chidambaram R. Nanotechnology in herbicide resistance. In: Nanostructured materials-fabrication to applications. London: IntechOpen; 2017. p. 207-12. https://doi.org/10.5772/intechopen.68355. Accessed 20 Nov 2020.

Adhikari T, Kundu S, Rao AS. Impact of $\mathrm{SiO}_{2}$ and Mo nanoparticles on seed germination of rice (Oryza sativa L.). Int J Agri Food Sci Technol. 2013;4(8): 809-16.

Ali S, Mehmood A, Khan N. Uptake, translocation, and consequences of nanomaterials on plant growth and stress adaptation. J Nanomater. 2021; 2021:6677616. https://doi.org/10.1155/2021/6677616.

Arora S, Sharma P, Kumar S, et al. Gold-nanoparticle induced enhancement in growth and seed yield of Brassica juncea. Plant Growth Regul. 2012;66(3): 303-10. https://doi.org/10.1007/s10725-011-9649-z.

Aslani F, Bagheri S, Muhd Julkapli N, et al. Effects of engineered nanomaterials on plants growth: an overview. Sci World J. 2014;2014:641759. https://doi.org/1 $0.1155 / 2014 / 641759$.

Assadian E, Zarei MH, Gilani AG, Farshin M, Degampanah H, Pourahmad J. Toxicity of copper oxide (CuO) nanoparticles on human blood lymphocytes. Biol Trace Elem Res. 2018;184(2):350-7. https://doi.org/10.1007/s12011-017-11 70-4.

Bala R, Kalia A, Dhaliwal SS. Evaluation of efficacy of ZnO nanoparticles as remedial zinc nanofertilizer for rice. J Soil Sci Plant Nutr. 2019;19(2):379-89. https://doi.org/10.1007/s42729-019-00040-z.

Barrena R, Casals E, Colón J, et al. Evaluation of the ecotoxicity of model nanoparticles. Chemosphere. 2009;75(7):850-7. https://doi.org/10.1016/j. chemosphere.2009.01.078.

Biba R, Tkalec M, Cvjetko P, et al. Silver nanoparticles affect germination and photosynthesis in tobacco seedlings. Acta Bot Croat. 2021:80(1):1. https://doi. org/10.37427/botcro-2020-029.

Boonyanitipong P, Kositsup B, Kumar P, et al. Toxicity of $\mathrm{ZnO}$ and $\mathrm{TiO}_{2}$ nanoparticles on germinating rice seed Oryza sativa L. Int J Biosci Biochem Bioinform. 2011;1(4):282. 
Da Costa M, Sharma P. Effect of copper oxide nanoparticles on growth, morphology, photosynthesis, and antioxidant response in Oryza sativa. Photosynthetica. 2016;54(1):110-9. https://doi.org/10.1007/s11099-015-0167-5.

Das P, Barua S, Sarkar S, et al. Plant extract-mediated green silver nanoparticles: efficacy as soil conditioner and plant growth promoter. J Hazard Mater. 2018; 346:62-72. https://doi.org/10.1016/j.jhazmat.2017.12.020.

de la Rosa G, López-Moreno ML, de Haro D, et al. Effects of ZnO nanoparticles in alfalfa, tomato, and cucumber at the germination stage: root development and X-ray absorption spectroscopy studies. Pure Appl Chem. 2013;85(12): 2161-74. https://doi.org/10.1351/pac-con-12-09-05.

Deshpande MV. Nanobiopesticide perspectives for protection and nutrition of plants. In: Koul O, editor. Nano-biopesticides today and future perspectives. London: Academic Press; 2019. p. 47-68. https://doi.org/10.1016/B978-0-12815829-6.00003-6.

Dimkpa C, Singh U, Adisa I, et al. Effects of manganese nanoparticle exposure on nutrient acquisition in wheat (Triticum aestivum L.). Agronomy. 2018;8(9):158. https://doi.org/10.3390/agronomy8090158.

Du W, Gardea-Torresdey JL, Ji R, et al. Physiological and biochemical changes imposed by $\mathrm{CeO}_{2}$ nanoparticles on wheat: a life cycle field study. Environ Sci Technol. 2015;49(19):11884-93. https://doi.org/10.1 021/acs.est.5b03055.

Du W, Sun Y, Ji R, et al. $\mathrm{TiO}_{2}$ and $\mathrm{ZnO}$ nanoparticles negatively affect wheat growth and soil enzyme activities in agricultural soil. J Environ Monit. 2011; 13(4):822-8. https://doi.org/10.1039/c0em00611d.

Dykman L, Shchyogolev S. The effect of gold and silver nanoparticles on plant growth and development. In: Saylor Y, Irby V, editors. Metal nanoparticles. New York: Nova; 2018. p. 63-300.

Ebrahimi A, Galavi M, Ramroudi M, et al. Effect of $\mathrm{TiO}_{2}$ nanoparticles on antioxidant enzymes activity and biochemical biomarkers in pinto bean (Phaseolus vulgaris L.). J Mol Biol Res. 2016;6(1):58. https://doi.org/10.5539/ jmbr.v6n1p58.

Elhawat N, Alshaal T, Hamad E, et al. Nanoparticle-associated phytotoxicity and abiotic stress under agroecosystems. In: Faisal M, Saquib Q, Alatar AA, AlKhedhairy AA, editors. Phytotoxicity of Nanoparticles. New York: Springer; 2018. p. 241-68. https://doi.org/10.1007/978-3-319-76708-6_10.

El-Temsah YS, Joner EJ. Impact of Fe and Ag nanoparticles on seed germination and differences in bioavailability during exposure in aqueous suspension and soil. Environ Toxicol. 2012;27(1):42-9. https://doi.org/10.1002/tox.20610.

Emamverdian A, Ding Y, Xie Y, Sangari S. Silicon mechanisms to ameliorate heavy metal stress in plants. Biomed Res Int. 2018;2018:8492898. https://doi.org/1 $0.1155 / 2018 / 8492898$.

Faizan M, Faraz A, Yusuf M, et al. Zinc oxide nanoparticle-mediated changes in photosynthetic efficiency and antioxidant system of tomato plants. Photosynthetica. 2018;56(2):678-86. https://doi.org/10.1007/s11099-017-07170 .

Falco WF, Scherer MD, Oliveira SL, et al. Phytotoxicity of silver nanoparticles on Vicia faba: evaluation of particle size effects on photosynthetic performance and leaf gas exchange. Sci Total Environ. 2020;701:134816. https://doi.org/1 0.1016/j.scitotenv.2019.134816.

Fytianos G, Rahdar A, Kyzas GZ. Nanomaterials in cosmetics: recent updates. Nanomaterials. 2020;10(5):979. https://doi.org/10.3390/nano10050979.

Gonzalez-Soto T, González-Mendoza D, Troncoso-Rojas R, et al. Molecular identification of Fusarium species isolated from transgenic insect-resistant cotton plants in Mexicali Valley, Baja California. Genet Mol Res. 2015;14(4): 11739-44. https://doi.org/10.4238/2015.october.2.7.

Gopinath K, Gowri S, Karthika V, Arumugam A. Green synthesis of gold nanoparticles from fruit extract of Terminalia arjuna, for the enhanced seed germination activity of Gloriosa superba. J Nanostruct Chem. 2014;4(3):115. https://doi.org/10.1007/s40097-014-0115-0.

Gorczyca A, Pociecha E, Maciejewska-Prończuk J, et al. Phytotoxicity of silver nanoparticles and silver ions toward common wheat. Surf Innov. 2021. https://doi.org/10.1680/jsuin.20.00094.

Gruyer N, Dorais M, Bastien C, et al. Interaction between silver nanoparticles and plant growth. International Symposium on New Technologies for Environment Control, Energy-Saving and Crop Production in Greenhouse and Plant. 2013. https://doi.org/10.17660/ActaHortic.2014.1037.105..

Haghighi M, da Silva JAT. The effect of $\mathrm{N}-\mathrm{TiO}_{2}$ on tomato, onion, and radish seed germination. J Crop Sci Biotech. 2014;17(4):221-7. https://doi.org/10.1007/s12 892-014-0056-7

Hao Y, Cao X, Ma C, et al. Potential applications and antifungal activities of engineered nanomaterials against gray mold disease agent Botrytis cinerea on rose petals. Front Plant Sci. 2017:8:1332. https://doi.org/10.3389/fpls.2017. 01332.

Hao Y, Yuan W, Ma C, et al. Engineered nanomaterials suppress turnip mosaic virus infection in tobacco (Nicotiana benthamiana). Environ Sci Nano. 2018; 5(7):1685-93. https://doi.org/10.1039/C8EN00014J.

Helaly MN, El-Metwally MA, El-Hoseiny $\mathrm{H}$, et al. Effect of nanoparticles on biological contamination of in vitro cultures and organogenic regeneration of banana. Aust J Crop Sci. 2014;8(4):612.

Hobson DW. Nanotoxicology: the toxicology of nanomaterials and nanostructures. Int J Toxicol. 2016;35(1):3-4. https://doi.org/10.1177/1091581 816631729.

Jaberzadeh A, Moaveni P, Moghadam HRT, et al. Influence of bulk and nanoparticles titanium foliar application on some agronomic traits, seed gluten and starch contents of wheat subjected to water deficit stress. Notulae Botanicae Horti Agrobotanici Cluj-Napoca. 2013;41(1):201-7. https:// doi.org/10.15835/nbha4119093.

Jacob DL, Borchardt JD, Navaratnam L, et al. Uptake and translocation of Ti from nanoparticles in crops and wetland plants. Int J Phytoremediation. 2013;15(2): 142-53. https://doi.org/10.1080/15226514.2012.683209.

Jalil SU, Ansari MI. Nanoparticles and abiotic stress tolerance in plants: synthesis, action, and signaling mechanisms. In: Iqbal M, Khan R, Reddy PS, et al., editors. Plant signaling molecules. Cambridge: Woodhead Publishing; 2019. p. 549-61. https://doi.org/10.1016/B978-0-12-816451-8.00034-4

Jeevanandam J, Barhoum A, Chan YS, et al. Review on nanoparticles and nanostructured materials: history, sources, toxicity and regulations. Beilstein J Nanotechnol. 2018;9:1050-74. https://doi.org/10.3762/bjnano.9.98.

Kango S, Kalia S, Celli A, et al. Surface modification of inorganic nanoparticles for development of organic-inorganic nanocomposites: a review. Prog Pol Sci. 2013;38(8):1232-61. https://doi.org/10.1016/j.progpolymsci.2013.02.003.

Konate A, He X, Zhang Z, et al. Magnetic $\left(\mathrm{Fe}_{3} \mathrm{O}_{4}\right)$ Nanoparticles reduce heavy metals uptake and mitigate their toxicity in wheat seedling. Sustainability. 2017;9(5):790. https://doi.org/10.3390/su9050790.

Kumar A, Gupta K, Dixit S, et al. A review on positive and negative impacts of nanotechnology in agriculture. Int J Environ Sci Technol. 2019;16(4):2175-84. https://doi.org/10.1007/s13762-018-2119-7.

Kumar V, Guleria P, Kumar V, Yadav SK. Gold nanoparticle exposure induces growth and yield enhancement in Arabidopsis thaliana. Sci Total Environ. 2013:461:462-8. https://doi.org/10.1016/j.scitotenv.2013.05.018.

Kurvet I, Juganson K, Vija H, et al. Toxicity of nine (doped) rare earth metal oxides and respective individual metals to aquatic microorganisms Vibrio fischeri and Tetrahymena thermophila. Materials. 2017;10(7):754. https://doi.org/10.3390/ ma10070754.

Lahiani MH, Dervishi E, Chen J, et al. Impact of carbon nanotube exposure to seeds of valuable crops. ACS Appl Mater Interfaces. 2013;5(16):7965-73. https://doi.org/10.1021/am402052x.

Lara-Romero J, Campos-García J, Dasgupta-Schubert N, et al. Biological effects of carbon nanotubes generated in forest wildfire ecosystems rich in resinous trees on native plants. PeerJ. 2017;5:e3658. https://doi.org/10.7717/peerj.3658.

Larue C, Laurette J, Herlin-Boime N, et al. Accumulation, translocation and impact of $\mathrm{TiO}_{2}$ nanoparticles in wheat (Triticum aestivum spp.): influence of diameter and crystal phase. Sci Total Environ. 2012;431:197-208. https://doi.org/10.101 6/j.scitotenv.2012.04.073.

Lee CW, Mahendra S, Zodrow K, et al. Developmental phytotoxicity of metal oxide nanoparticles to Arabidopsis thaliana. Environ Toxicol Chem Int J. 2010; 29(3):669-75. https://doi.org/10.1002/etc.58.

Lee WM, Kwak JI, An YJ. Effect of silver nanoparticles in crop plants Phaseolus radiatus and Sorghum bicolor: media effect on phytotoxicity. Chemosphere. 2012;86(5):491-9. https://doi.org/10.1016/j.chemosphere.2011.10.013.

Li X, Gui X, Rui Y, et al. Bt-transgenic cotton is more sensitive to $\mathrm{CeO}_{2}$ nanoparticles than its parental non-transgenic cotton. J Hazard Mater. 2014; 274:173-80. https://doi.org/10.1016/j.jhazmat.2014.04.025.

Lin D, Xing B. Phytotoxicity of nanoparticles: inhibition of seed germination and root growth. Environ Pollut. 2007;150(2):243-50. https://doi.org/10.1016/j. envpol.2007.01.016.

LV J, Christie P, Zhang S. Uptake, translocation, and transformation of metalbased nanoparticles in plants: recent advances and methodological challenges. Environ Sci Nano. 2019;6(1):41-59. https://doi.org/10.1039/ C8EN00645H.

Ma C, Chhikara S, Xing B, et al. Physiological and molecular response of Arabidopsis thaliana (L.) to nanoparticle cerium and indium oxide exposure. ACS Sustain Chem Eng. 2013;1(7):768-78. https://doi.org/10.1021/sc400098h. 
Mahmoodzadeh $\mathrm{H}$, Nabavi M, Kashefi $\mathrm{H}$. Effect of nanoscale titanium dioxide particles on the germination and growth of canola (Brassica napus). J Ornam Hortic Plants. 2013;3:25-32.

McGee C, Storey S, Clipson N, et al. Soil microbial community responses to contamination with silver, aluminium oxide and silicon dioxide nanoparticles. Ecotoxicology. 2017;26(3):449-58. https://doi.org/10.1007/s10646-017-1776-5.

Mehboob-ur-Rahman ST, Tabbasam N, et al. Cotton genetic resources. A review. Agron Sustain Dev. 2012;32(2):419-32. https://doi.org/10.1007/s13593-011-0051-z

Mei L, Li L, Daud MK, et al. Advances on response and resistance to heavy metal stress in cotton. Cotton Sci. 2018;30(1):102-10. https://doi.org/10.11963/10027807.mlzsj.20171107.

Meyer K, Rajanahalli P, Ahamed M, et al. ZnO Nanoparticles induce apoptosis in human dermal fibroblasts via p53 and p38 pathways. Toxicol in Vitro. 2011; 25(8):1721-6. https://doi.org/10.1016/j.tiv.2011.08.011.

Mukesh AT, Jha A. A review on: Carbon nanotubes are vital for plant growth. Am J Agric Forestry. 2017;5(5-1):1-9. https://doi.org/10.11648/j.ajaf.s.201 7050501.11.

Mukherjee A, Sun Y, Morelius E. Differential toxicity of bare and hybrid ZnO nanoparticles in green pea (Pisum sativum L.): a life cycle study. Front Plant Sci. 2016;6:1242. https://doi.org/10.3389/fpls.2015.01242.

Mukherjee A, Peralta-Videa JR, Bandyopadhyay S, et al. Physiological effects of nanoparticulate $\mathrm{ZnO}$ in green peas (Pisum sativum L.) cultivated in soil. Metallomics. 2014;6(1):132-8.https://doi.org/10.1039/c3mt00064h .

Nair PMG, Chung IM. Physiological and molecular level effects of silver nanoparticles exposure in rice (Oryza sativa L.) seedlings. Chemosphere. 2014 112:105-13. https://doi.org/10.1016/j.chemosphere.2014.03.056.

Nair R. Effects of nanoparticles on plant growth and development. In: Kole C, Kumar DS, Riya V, Khodakovskaya MV, editors. Plant nanotechnology: principles and practices. New York: Springer; 2016. p. 95-118. https://doi. org/10.1007/978-3-319-42154-4_5.

Nehra A, Ahlawat S, Singh KP. A biosensing expedition of nanopore: a review. Sens Actuators B Chem. 2019;284:595-622. https://doi.org/10.1016/j.snb.2018.12.143.

Nhan LV, Ma C, Rui Y, et al. Phytotoxic mechanism of nanoparticles: destruction of chloroplasts and vascular bundles and alteration of nutrient absorption. Sci Rep. 2015;5:11618. https://doi.org/10.1038/srep11618.

Nhan LV, Ma C, Rui Y, et al. The effects of $\mathrm{Fe}_{2} \mathrm{O}_{3}$ nanoparticles on physiology and insecticide activity in non-transgenic and Bt-transgenic cotton. Front Plant Sci. 2016a;6:1263. https://doi.org/10.3389/fpls.2015.01263.

Nhan LV, Ma C, Shang J, et al. Effects of CuO nanoparticles on insecticidal activity and phytotoxicity in conventional and transgenic cotton. Chemosphere. 2016b;144:661-70. https://doi.org/10.1016/j.chemosphere.2015.09.028.

Nhan LV, Rui Y, Cao W, et al. Toxicity and bio-effects of CuO nanoparticles on transgenic Ipt-cotton. J Plant Interactions. 2016c;11(1):108-16. https://doi. org/10.1080/17429145.2016.1217434.

Nhan LV, Rui Y, Gui X, et al. Uptake, transport, distribution and bio-effects of $\mathrm{SiO}_{2}$ nanoparticles in Bt-transgenic cotton. J Nanobiotech. 2014;12(1):50. https:// doi.org/10.1186/s12951-014-0050-8.

Nie Z, Petukhova A, Kumacheva E. Properties and emerging applications of selfassembled structures made from inorganic nanoparticles. Nat Nanotechnol. 2010;5(1):15-25. https://doi.org/10.1038/nnano.2009.453.

Nix A, Paull C, Colgrave M. Flavonoid profile of the cotton plant, Gossypium hirsutum: a review. Plants. 2017;6(4):43. https://doi.org/10.3390/plants6040043.

Oloumi H, Mousavi EA, Nejad RM. Multi-wall carbon nanotubes effects on plant seedlings growth and cadmium/lead uptake in vitro. Russ J Plant Physiol. 2018;65(2):260-8. https://doi.org/10.1134/S102144371802019X.

Patel A, Tiwari S, Parihar P, et al. Carbon nanotubes as plant growth regulators: impacts on growth, reproductive system, and soil microbial community. In: Tripathi DK, Ahmad P, Sharma S, et al., editors. Nanomaterials in plants, algae and microorganisms. London: Academic; 2017. p. 23-42. https://doi.org/10.1 002/smll.201201225.

Peharec ŠP, Košpić K, Lyons DM, et al. Phytotoxicity of silver nanoparticles on tobacco plants: evaluation of coating effects on photosynthetic performance and chloroplast ultrastructure. Nanomaterials. 2021;11(3):744. https://doi.org/1 0.3390/nano11030744.

Pradhan S, Patra P, Das S, et al. Photochemical modulation of biosafe manganese nanoparticles on Vigna radiata: a detailed molecular, biochemical, and biophysical study. Environ Sci Technol. 2013;47(22):13122-31. https://doi. org/10.1021/es402659t.

Prasad T, Sudhakar P, Sreenivasulu Y, et al. Effect of nanoscale zinc oxide particles on the germination, growth and yield of peanut. J Plant Nutr. 2012;35(6): 905-27. https://doi.org/10.1080/01904167.2012.663443.
Priester JH, Moritz SC, Espinosa K, et al. Damage assessment for soybean cultivated in soil with either $\mathrm{CeO}_{2}$ or $\mathrm{ZnO}$ manufactured Nanomaterials. Sci Total Environ. 2017;579:1756-68. https://doi.org/10.1016/j.scitotenv.2016.11.149.

Rajput V, Minkina T, Suskova S, et al. Effects of copper nanoparticles (CuO NPs) on crop plants: a mini review. BioNanoScience. 2018;8(1):36-42. https://doi. org/10.1007/s12668-017-0466-3.

Rajput VD, Minkina T, Sushkova S, et al. Effect of nanoparticles on crops and soil microbial communities. J Soils Sediments. 2017;18(6):2179-87. https://doi. org/10.1007/s11368-017-1793-2.

Raskar S, Laware S. Effect of zinc oxide nanoparticles on cytology and seed germination in onion. Int J Curr Microbiol Appl Sci. 2014;3(2):467-73.

Rastogi A, Zivcak M, Sytar O, et al. Impact of metal and metal oxide nanoparticles on plant: a critical review. Front Chem. 2017;5:78. https://doi.org/10.3389/ fchem.2017.00078.

Rico CM, Lee SC, Rubenecia R, et al. Cerium oxide nanoparticles impact yield and modify nutritional parameters in wheat (Triticum aestivum L.). J Agric Food Chem. 2014;62(40):9669-75. https://doi.org/10.1021/jf503526r.

Rizwan M, Ali S, Ali B, et al. Zinc and iron oxide nanoparticles improved the plant growth and reduced the oxidative stress and cadmium concentration in wheat. Chemosphere. 2019;214:269-77. https://doi.org/10.1016/j. chemosphere.2018.09.120.

Roh JY, Choi JY, Li MS, et al. Bacillus thuringiensis as a specific, safe, and effective tool for insect pest control. J Microbiol Biotechnol. 2007;17(4):547-59.

Ruttkay-Nedecky B, Krystofova O, Nejdl L, Adam V. Nanoparticles based on essential metals and their phytotoxicity. J Nanobiotechnology. 2017;15(1):33. https://doi.org/10.1186/s12951-017-0268-3.

Salama HM. Effects of silver nanoparticles in some crop plants, common bean (Phaseolus vulgaris L.) and corn (Zea mays L.). Int Res J Biotechnol. 2012; 3(10):190-7.

Salata OV. Applications of nanoparticles in biology and medicine. J Nanobiotech. 2004;2(1):3. https://doi.org/10.1186/1477-3155-2-3.

Sawan ZM. Cotton production and climatic factors: studying the nature of its relationship by different statistical methods. Cogent Biol. 2017;3(1):1292882. https://doi.org/10.1080/23312025.2017.1292882.

Sedghi M, Hadi M, Toluie SG. Effect of nano zinc oxide on the germination parameters of soybean seeds under drought stress. Ann West Univ Timisoara Biol. 2013;16(2):73.

Sekoai PT, Ouma CNM, du Preez SP, et al. Application of nanoparticles in biofuels: an overview. Fuel. 2019;237:380-97. https://doi.org/10.1016/j.fuel.2018.10.030.

Sharma P, Bhatt D, Zaidi M, et al. Silver nanoparticle-mediated enhancement in growth and antioxidant status of Brassica juncea. Appl Biochem Biotechnol. 2012;167(8):2225-33. https://doi.org/10.1007/s12010-012-9759-8.

Siddiqui $\mathrm{MH}$, Al-Whaibi MH, Firoz M, et al. Role of nanoparticles in plants, nanotechnology and plant sciences: nanoparticles and their impact on plants. Dordrecht: Springer; 2015. https://doi.org/10.1007/978-3-319-14502-0.

Singh AK. Engineered nanoparticles. Cambridge: Academic Press; 2016. p. 1-18.

Singh D, Kumar A. Impact of irrigation using water containing $\mathrm{CuO}$ and $\mathrm{ZnO}$ nanoparticles on Spinach oleracea grown in soil media. Bull Environ Contam Toxicol. 2016;97(4):548-53. https://doi.org/10.1007/s00128-016-1872-x.

Song H. Metal hybrid nanoparticles for catalytic organic and photochemical transformations. Acc Chem Res. 2015;48(3):491-9. https://doi.org/10.1021/ar500411s.

Sosan A, Svistunenko D, Straltsova D, et al. Engineered silver nanoparticles are sensed at the plasma membrane and dramatically modify the physiology of Arabidopsis thaliana plants. Plant J. 2016;85(2):245-57. https://doi.org/1 0.1111/tpj.13105.

Shabbir S, Kulyar M FeA, Bhutta ZA, et al. Toxicological consequences of titanium dioxide nanoparticles $\left(\mathrm{TiO}_{2} \mathrm{NPS}\right)$ and their jeopardy to human population. BioNanoSci. 2021. https://doi.org/10.1007/s12668-021-00836-3.

Srinivasan C, Saraswathi R. Nano-agriculture-carbon nanotubes enhance tomato seed germination and plant growth. Curr Sci. 2010;99(3):274-5.

Srivastav AK, Kumar M, Ansari NG, et al. A comprehensive toxicity study of zinc oxide nanoparticles versus their bulk in wistar rats: toxicity study of zinc oxide nanoparticles. Hum Exp Toxicol. 2016;35(12):1286-304. https://doi.org/1 0.1177/0960327116629530.

Suriyaprabha R, Karunakaran G, Yuvakkumar R, et al. Silica nanoparticles for increased silica availability in maize (Zea mays L.) seeds under hydroponic conditions. Curr Nanosci. 2012;8(6):902-8. https://doi.org/10.2174/157341312 803989033.

Syu YY, Hung JH, Chen JC, Chuang HW. Impacts of size and shape of silver nanoparticles on arabidopsis plant growth and gene expression. Plant Physiol Biochem. 2014;83:57-64. https://doi.org/10.1016/j.plaphy.2014.07.010. 
Taylor AF, Rylott EL, Anderson CW, et al. Investigating the toxicity, uptake, nanoparticle formation and genetic response of plants to gold. PLoS One. 2014;9(4):e93793. https://doi.org/10.1371/journal.pone.0093793.

Thorp K, Ale S, Bange M, et al. Development and application of process-based simulation models for cotton production: a review of past, present, and future directions. J Cotton Sci. 2014;18(1):10-47.

Thuesombat P, Hannongbua S, Akasit S, Chadchawan S. Effect of silver nanoparticles on rice (Oryza sativa L. CV. KDML 105) seed germination and seedling growth. Ecotoxicol Environ Saf. 2014;104:302-9. https://doi.org/10.1 016/j.ecoenv.2014.03.022.

Umar H, Kavaz D, Rizaner N. Biosynthesis of zinc oxide nanoparticles using Albizia lebbeck stem bark, and evaluation of its antimicrobial, antioxidant, and cytotoxic activities on human breast cancer cell lines. Int J Nanomedicine. 2019;14:87-100. https://doi.org/10.2147/IJN.S186888.

Ursache-Oprisan M, Focanici E, Creanga D, et al. Sunflower chlorophyll levels after magnetic nanoparticle supply. Afr J Biotechnol. 2011;10(36):7092-8. https:// doi.org/10.5897/AJB11.477.

Vajpayee $\mathrm{P}$, Khatoon I, Patel CB, et al. Adverse effects of chromium oxide nanoparticles on seed germination and growth in Triticum aestivum L. J Biomed Nanotechnol. 2011;7(1):205-6. https://doi.org/10.1166/jbn.2011.1270.

Venkatachalam P, Priyanka N, Manikandan K, et al. Enhanced plant growth promoting role of phycomolecules coated zinc oxide nanoparticles with $\mathrm{P}$ supplementation in cotton (Gossypium hirsutum L.). Plant Physiol Biochem. 2017;110:118-27. https://doi.org/10.1016/j.plaphy.2016.09.004.

Vera-Reyes I, Vázquez-Núñez E, Lira-Saldivar RH, Méndez-Argüello B. Effects of nanoparticles on germination, growth, and plant crop development. In: López-Valdez F, Fernández-Luqueño F, editors. Agricultural nanobiotechnology: modern agriculture for a sustainable future. New York: Springer; 2018. p. 77-110. https://doi.org/10.1007/978-3-319-96719-6_5.

Wang A, Zheng Y, Peng F. Thickness-controllable silica coating of CdTe QDs by reverse microemulsion method for the application in the growth of rice. J Spectrosc. 2014;2014:1-5. https://doi.org/10.1155/2014/169245.

Wang Q, Ma X, Zhang W, et al. The impact of cerium oxide nanoparticles on tomato (Solanum lycopersicum L.) and its implications for food safety. Metallomics. 2012a;4(10):1105-12. https://doi.org/10.1039/c2mt20149f.

Wang Z, Xie X, Zhao J, et al. Xylem-and phloem-based transport of CuO nanoparticles in maize (Zea mays L.). Environ Sci Technol. 2012b;46(8):443441. https://doi.org/10.1021/es204212z.

Wegier A, Alavez V, Piñero D. Cotton: traditional and modern uses. In: Lira R, Casas A, Blancas J, editors. Ethnobotany of Mexico: interactions of people and plants in Mesoamerica. New York: Springer; 2016. p. 439-56. https://doi. org/10.1007/978-1-4614-6669-7_18.

Witjaksono J, Wei X, Mao S, et al. Yield and economic performance of the use of GM cotton worldwide over time: a review and meta-analysis. China Agr Econ Rev. 2014;6(4):616-43. https://doi.org/10.1108/CAER-02-2013-0028.

Worrall E, Hamid A, Mody K, et al. Nanotechnology for plant disease management. Agronomy. 2018;8(12):285. https://doi.org/10.3390/a gronomy 8120285

Xu SJ, Fang D, Tian XQ, et al. Analysis and assessment on heavy metal contamination in cotton seeds of Hunan Province. Cotton Sci. 2019;31(1):728. https://doi.org/10.11963/1002-7807.xsjml.20190122.

Yang A, Qi M, Wang X, et al. Refined cottonseed oil as a replacement for soybean oil in broiler diet. Food Sci Nutr. 2019;7(3):1027-34. https://doi.org/1 $0.1002 / f_{s} n 3.933$

Yang J, Cao W, Rui Y. Interactions between nanoparticles and plants: phytotoxicity and defense mechanisms. J Plant Interactions. 2017;12(1):15869. https://doi.org/10.1080/17429145.2017.1310944.

Yang L, Watts DJ. Particle surface characteristics may play an important role in phytotoxicity of alumina nanoparticles. Toxicol Lett. 2005;158(2):122-32. https://doi.org/10.1016/j.toxlet.2005.03.003.

Yanık F, Vardar F. Toxic effects of aluminum oxide $\left(\mathrm{Al}_{2} \mathrm{O}_{3}\right)$ nanoparticles on root growth and development in Triticum aestivum. Water Air Soil Poll. 2015; 226(9):296. https://doi.org/10.1007/s11270-015-2566-4.

Yoon SJ, Kwak JI, Lee WM, et al. Zinc oxide nanoparticles delay soybean development: a standard soil microcosm study. Ecotoxicol Environ Saf. 2014; 100:131-7. https://doi.org/10.1016/j.ecoenv.2013.10.014

Zhao L, Peralta-Videa JR, Armando VR, et al. Effect of surface coating and organic matter on the uptake of $\mathrm{CeO}_{2} \mathrm{NPs}$ by corn plants grown in soil: insight into the uptake mechanism. J Hazard Mater. 2012;225:131-8. https://doi.org/10.1 016/j.jhazmat.2012.05.008.
Zhao L, Sun Y, Hernandez-Viezcas JA, et al. Influence of $\mathrm{CeO}_{2}$ and $\mathrm{ZnO}$ nanoparticles on cucumber physiological markers and bioaccumulation of Ce and Zn: a life cycle study. J Agric Food Chem. 2013;61(49):11945-51. https://doi.org/10.1021/jf404328e.

Zhu Y, Xu F, Liu Q, et al. Nanomaterials and plants: positive effects, toxicity and the remediation of metal and metalloid pollution in soil. Sci Total Environ. 2019;662:414-21. https://doi.org/10.1016/j.scitotenv.2019.01.234.
Ready to submit your research? Choose BMC and benefit from:

- fast, convenient online submission

- thorough peer review by experienced researchers in your field

- rapid publication on acceptance

- support for research data, including large and complex data types

- gold Open Access which fosters wider collaboration and increased citations

- maximum visibility for your research: over $100 \mathrm{M}$ website views per year

At $\mathrm{BMC}$, research is always in progress.

Learn more biomedcentral.com/submissions 